University of Nebraska - Lincoln

DigitalCommons@University of Nebraska - Lincoln

2-21-2019

\title{
Newgeochemical evidence for the origin of North America's largest dune field, the Nebraska Sand Hills, central Great Plains, USA
}

Daniel R. Muhs

James R. Budahn

Follow this and additional works at: https://digitalcommons.unl.edu/usgsstaffpub

Part of the Geology Commons, Oceanography and Atmospheric Sciences and Meteorology Commons, Other Earth Sciences Commons, and the Other Environmental Sciences Commons

This Article is brought to you for free and open access by the US Geological Survey at DigitalCommons@University of Nebraska - Lincoln. It has been accepted for inclusion in USGS Staff -- Published Research by an authorized administrator of DigitalCommons@University of Nebraska - Lincoln. 


\title{
New geochemical evidence for the origin of North America's largest dune field, the Nebraska Sand Hills, central Great Plains, USA
}

\author{
Daniel R. Muhs *, James R. Budahn \\ U.S. Geological Survey, MS 980, Box 25046, Federal Center, Denver, CO 80225, USA
}

\section{A R T I C L E I N F O}

\section{Article history:}

Received 5 November 2018

Received in revised form 18 February 2019

Accepted 19 February 2019

Available online 21 February 2019

\section{Keywords}

Nebraska Sand Hills

Dune field

Trace element geochemistry

Provenance

Pliocene sands

Platte River system

Arikaree Group

Ogallala Group

Dissection

\begin{abstract}
A B S T R A C T
The Nebraska Sand Hills region is the largest dune field in North America and has diverse aeolian landforms. It has been active during both the late Pleistocene and late Holocene. Despite decades of study, the source of sediment for this large sand sea is still controversial. Here we report new trace element compositions of aeolian sand that are compared to four hypothesized sediment sources, Tertiary rocks of the Arikaree Group and Ogallala Group, unconsolidated sands of Pliocene age, and Platte River system sands. All four potential sources have a mineralogy that is similar to the Nebraska Sand Hills. K/Rb, K/Ba, Sc-Th-La, Eu/Eu*, $\mathrm{La}_{\mathrm{N}} / \mathrm{Yb}_{\mathrm{N}}, \mathrm{As} / \mathrm{Sb}$, and Fe/Sc values show, however, that Pliocene sediments and sands from the Platte River system are not likely sources. The Arikaree Group could be a minor contributor, but sands from the Ogallala Group appear to have the best compositional fit to the Nebraska Sand Hills. Although past studies have proposed the Ogallala Group as an important sand source, the hypothesis has been questioned, because the unit is well cemented by calcrete in its upper part. However, examination of the landscape upwind of the Nebraska Sand Hills shows that the Ogallala Group, where it occurs at the land surface, is highly dissected in much of this region, which makes sand-sized particles available for aeolian entrainment whenever drought conditions diminish a protective vegetation cover.
\end{abstract}

Published by Elsevier B.V.

\section{Introduction}

Dune fields of Quaternary age occupy large areas of the world's arid and semiarid regions, many of them in subtropical deserts and in rainshadowed zones of the mid-latitudes (Wilson, 1973; Lancaster, 1989, 1995; Pye and Tsoar, 1990; Cooke et al., 1993; Lancaster, 1989, 1995; Livingstone and Warren, 1996; Goudie, 2002; Muhs et al., 2013; Warren, 2013; Lorenz and Zimbelman, 2014). Some of the largest dune fields, in the deserts of Asia and Africa, are unvegetated and fully active (Yang et al., 2004; Lancaster, 2007; Sun and Muhs, 2007). In contrast, dune fields of South America and North America are mostly vegetated and inactive (Zárate and Tripaldi, 2012; Muhs, 2017). In Australia, dune fields are also largely inactive, but dune field stabilization is due not only to vegetation cover, but also cementation and pedogenesis (Hesse, 2011).

Whether a dune field is active or stable, as well as what sort of dune forms evolve, requires an understanding of the controls on sand entrainment, transport, and deposition. More than seven decades ago, Hack (1941) articulated what are now considered to be the main variables in dune field activity and evolution, namely sand supply, wind strength, and degree of vegetation cover. Later studies have emphasized the importance of climatic factors, primarily moisture balance (precipitation vs.

\footnotetext{
* Corresponding author.

E-mail address: dmuhs@usgs.gov (D.R. Muhs).
}

evapotranspiration) as controls on the degree of vegetation cover on sand dunes (Lancaster, 1988; Muhs and Maat, 1993; Muhs and Holliday, 1995; Wolfe, 1997; Lancaster and Helm, 2000). Still other studies have proposed wind strength as the dominant climate factor in explaining degree of dune activity (Tsoar, 2005; Tsoar et al., 2009; Yizhaq et al., 2009). All of these studies assume, however, that sand supply is adequate to form a dune field in the first place. Thus, understanding the source or sources of sand is key to understanding the origin and subsequent evolution of a dune field. In support of this concept, Kocurek and Lancaster (1999) proposed the idea of an "aeolian system sediment state," which includes, within a dune field, the degree of aeolian activity vs. stability. These investigators emphasized the components of sediment supply and sediment availability, in addition to transport capacity of the wind. Halfen et al. (2016), in a recent review of North American dune fields of late Quaternary age, also emphasized the importance of sediment supply and sediment availability (as a result of drought episodes) as controls on dune field activity. Thus, provenance of sand is fundamental to understanding the genesis of a dune field and its potential for future activity.

Inland dune fields of Quaternary age, most of them stabilized by vegetation, are common across much of North America (see reviews in Wolfe, 2007 and Muhs, 2017). Within the USA, areas of aeolian sand are concentrated in three physiographic regions, the Basin and Range, the Colorado Plateau, and the Great Plains (Fig. 1). The largest areas of aeolian sand are those within the Great Plains province (Fig. 2). The Great Plains region is semiarid because it lies within the rain shadow 


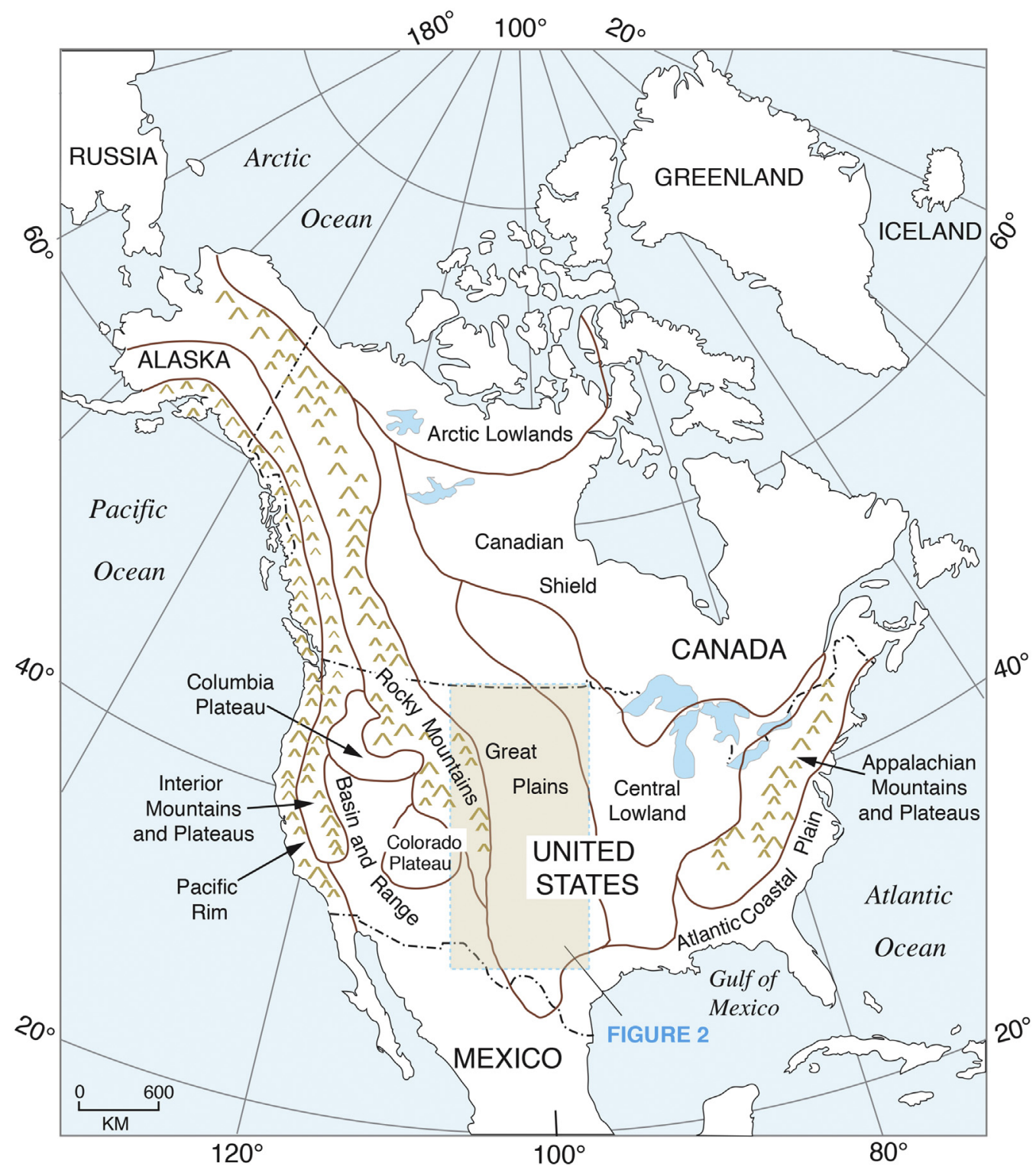

Fig. 1. Map of North America showing physiographic provinces. Dashed box outlines the Great Plains physiographic province within the USA (Fig. 2).

of the north-south-trending ranges of the Rocky Mountains, which shield the region to the east from westerly storm tracks. Active aeolian sand in the Great Plains region is limited to the southernmost dunes in Texas and New Mexico and a few other areas where human activities, such as grazing, cultivation, or development of infrastructure have reactivated previously stabilized sand.

The Nebraska Sand Hills dune field, in the central part of the Great Plains, covers an area of $\sim 57,000 \mathrm{~km}^{2}$ (Fig. 2). Much of the dune field was active during the last glacial period, based on extensive drilling and optically stimulated luminescence (OSL) dating reported in a landmark study by Mason et al. (2011). Although most dunes in the Nebraska Sand Hills are presently stabilized by vegetation, there is ample evidence that sand also has been active within the late Holocene, based on radiocarbon and OSL dating (Ahlbrandt et al., 1983; Swinehart, 1990; Loope et al., 1995; Muhs et al., 1997; Stokes and Swinehart, 1997; Goble et al., 2004; Mason et al., 2004; Forman et al., 2005; Miao et al., 2007; Schmeisser et al., 2010; Schmeisser McKean et al., 2015) and even historical accounts (Muhs and Holliday, 1995). These studies have shown that this large dune field is highly sensitive to changes in moisture regime that control the degree of stabilizing vegetation.
Although there has been a significant effort to understand the timing of dune activity in the Nebraska Sand Hills, there have been few studies of the actual sources of the sand. Recently, Muhs (2017) re-examined the origin of many of the dune fields of the Great Plains and Basin and Range provinces. This investigation utilized $\mathrm{K} / \mathrm{Rb}$ and $\mathrm{K} / \mathrm{Ba}$ values as proxies for the compositions of K-feldspars from different source sediments. Results show that some previous concepts of dune field origins are supported by the new data, some dune sand sources not previously considered to be important are actually significant contributors, and the origin of some dune fields still remains elusive. One of the dune fields whose source sediments are still uncertain is the Nebraska Sand Hills.

In the Nebraska Sand Hills region, modern observations show that on an annual basis, the dominant sand-moving winds (computed as resultant drift directions, or RDD, using methods of Fryberger and Dean, 1979) come from the northwest (Fig. 3). Late Holocene paleowinds, based on the orientations of parabolic dunes examined on aerial photographs, indicate that the dominant sand-moving winds were also from the northwest (Fig. 3). Thus, a simple interpretation might be that past wind directions were similar to those of the present and sources of the Nebraska Sand Hills must lie to the northwest of the dune field. However, in a continental-interior, mid-latitude region such as Nebraska, there are 


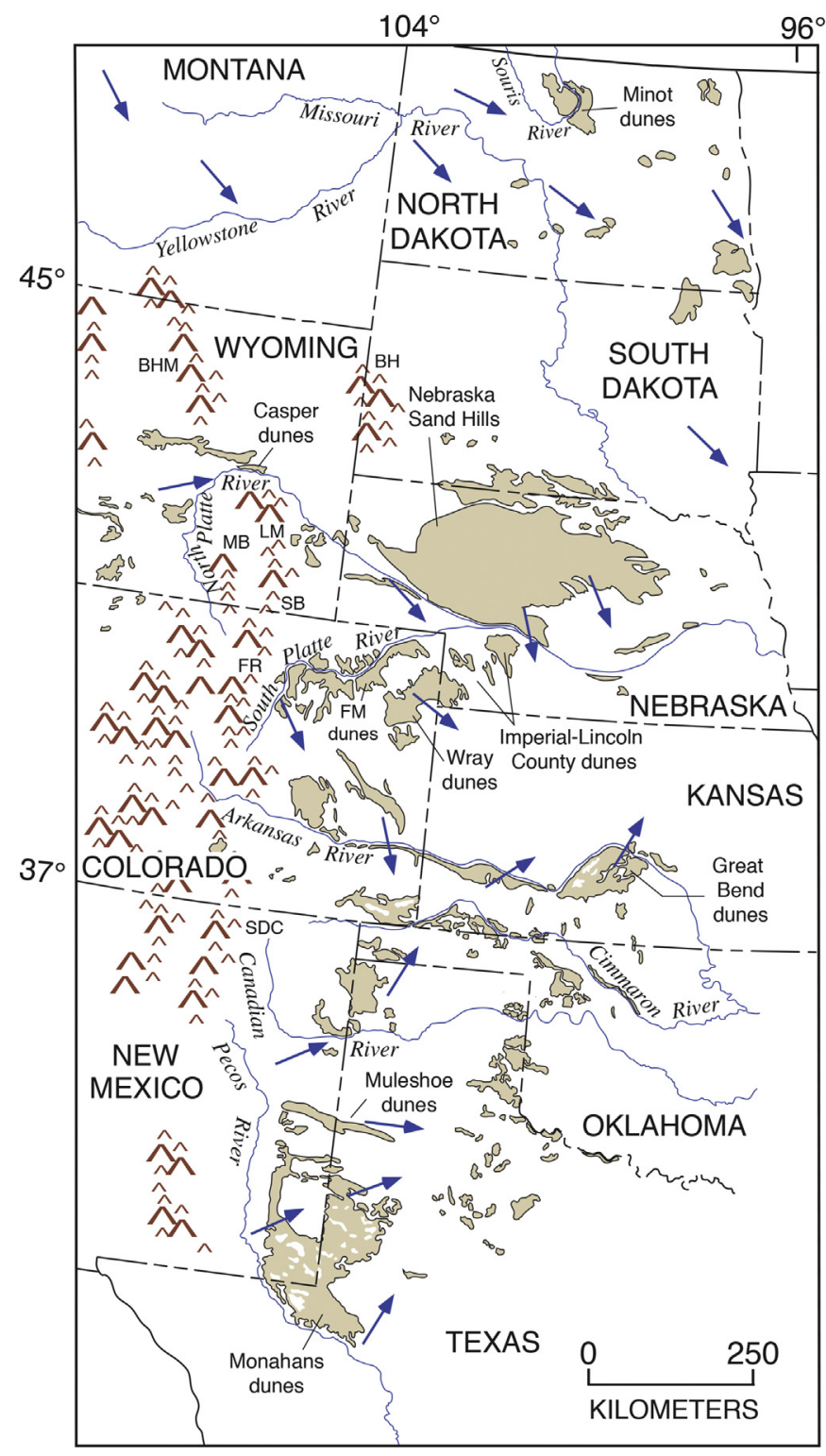

Fig. 2. Map of the Great Plains region in the central USA, showing the distribution of dune fields and annual wind RDD (resultant drift direction; see Fryberger and Dean, 1979). Aeolian sand distribution modified slightly from compilation in Muhs and Holliday (1995), who used the following sources: Dane and Bachman (1965), Morrison (1969), Westin et al. (1971), Scott $(1968,1978)$, Sharps $(1976,1980)$, Love and Christiansen (1985), Swinehart (1990), Kuzila et al. (1990), Ross et al. (1991), Hartman and Scranton (1992), Swinehart et al. (1994a), and Muhs et al. (1996). Most areas mapped here were also field-checked by the authors; see also digital form of this distribution in Soller and Reheis (2004). Arrows show RDD values of modern, sand-moving winds calculated by the authors. Abbreviations: BH, Black Hills; BHM, Bighorn Mountains; LM, Laramie Mountains; MB, Medicine Bow Mountains; SB, Sherman batholith; FR, Front Range; FM, Fort Morgan; SDC, Sangre de Cristo Mountains.

strong seasonal contrasts in temperature, precipitation, and wind direction. During October through April, the RDD of sand-moving winds in Nebraska are dominantly from the northwest (represented in Fig. 4a by RDD for April). However, during winter months, soils and sediments of the central Great Plains are frozen and/or snow-covered for extended periods, limiting particle mobility by wind. In contrast, during the warmer months of May through September, although resultant drift potential (RDP) values are lower, meaning weaker winds, many localities in Nebraska show sand-moving winds dominantly from the south, southwest, or southeast (represented in Fig. 4b by RDD for August). Thus, although dune sand sources in areas situated to the northwest of the Nebraska Sand Hills might be important in the cooler months of the year, dune sand sources to the south, southwest, or southeast may be more important during the warmer months.

Trace element geochemistry is a powerful tool for investigating the origin of dune fields, particularly those with high quartz content, where major element geochemistry may provide only limited interpretations. A number of investigators have used trace element compositions, including the rare earth elements (REE) to determine the origin of dune fields in Mexico (Kasper-Zubillaga et al., 2007), China (Yang et al., 2007; Liu and Yang, 2018), and Africa (Garzanti et al., 2012). Here, four potential sources of aeolian sand for the Nebraska Sand Hills, identical to those studied by Muhs (2017) are considered in light of a larger suite of trace elements.

Potential source sediments for the Nebraska Sand Hills span a considerable range of geologic ages. One of these sources is unconsolidated fluvial sediments, sands from the Platte River system (North Platte, South Platte and Platte rivers), situated to the west, southwest, south, and southeast of the dune field (Fig. 5). Other potential source sediments for the Nebraska Sand Hills are of pre-Quaternary age. Pliocene sheet sands, some of which are thought to be of aeolian origin, occur beneath the Nebraska Sand Hills. These sediments, mostly unconsolidated, are as much as $28 \mathrm{~m}$ thick. The full geographic extent of these Pliocene sands is unknown, but a minimum distribution has been documented by Myers (1993), Swinehart et al. (1994b), and May et al. (1995), primarily beneath the south-central part of the Nebraska Sand Hills (Fig. 5). In the present study, samples were analyzed from localities where Pliocene sands are exposed either in quarries or along cut banks of streams. Two other potential dune sand sources, exposed to the northwest of the Nebraska Sand Hills, are the Miocene Ogallala Group and the Oligocene-Miocene Arikaree Group. These rocks occur at both the surface and subsurface over much of western Nebraska and adjacent parts of southern South Dakota, eastern Wyoming, and northeastern Colorado (Figs. 3 and 5). Some sediments of the Ogallala Group and Arikaree Group are well cemented due to long-term diagenesis or pedogenesis, but other occurrences of these units are loose, unconsolidated sands. Sediments of the Niobrara River valley, situated to the northwest and north of the Nebraska Sand Hills, are also a potential source, but because this river drains only rocks of the Arikaree and Ogallala Groups (Burchett, 1969; Love and Christiansen, 1985), possible contributions from it can be assessed from those two sources.

\section{Methods}

Aeolian sands from the Nebraska Sand Hills were sampled from unaltered sediments found below the modern soil. These were analyzed as bulk samples, with no pretreatments other than pulverization. Alluvial and bedrock samples from potential source sediments were sampled from outcrops and road cuts in Nebraska, Wyoming, and South Dakota. All source sediment samples were pretreated to yield a particle-size distribution similar to that of aeolian sand. After disaggregation and removal of coarse gravel, the samples were placed in deionized water, a Na-pyrophosphate dispersant was added, particles in suspension were stirred, and then allowed to sit overnight. After this treatment, the samples were stirred again by ultrasonication and then wet-sieved to remove fine gravel and the coarsest sands using a 500- $\mu \mathrm{m}$ sieve. Silt and clay were removed by wet-sieving with a $53-\mu \mathrm{m}$ sieve. Thus, the final sediment separates, $500 \mu \mathrm{m}-53 \mu \mathrm{m}$, contain grains ranging from medium sand to very fine sand, similar to the size range of aeolian sediments of the Nebraska Sand Hills (Ahlbrandt and Fryberger, 1980). Sample localities are shown in Fig. 5 and specific coordinates and analytical data are given in Supplementary Data Table 1.

Muhs et al. (1997) compared the relative abundances of quartz, Kfeldspar, and plagioclase in the Nebraska Sand Hills with those of dune sands in nearby eastern Colorado. Here, we use the same mineralogical data reported in that study for the Nebraska Sand Hills, but we compare these compositions to the mineralogy of the $500-\mu \mathrm{m}$ to $53-\mu \mathrm{m}$ separates of candidate source sediments, prepared as described above. We 

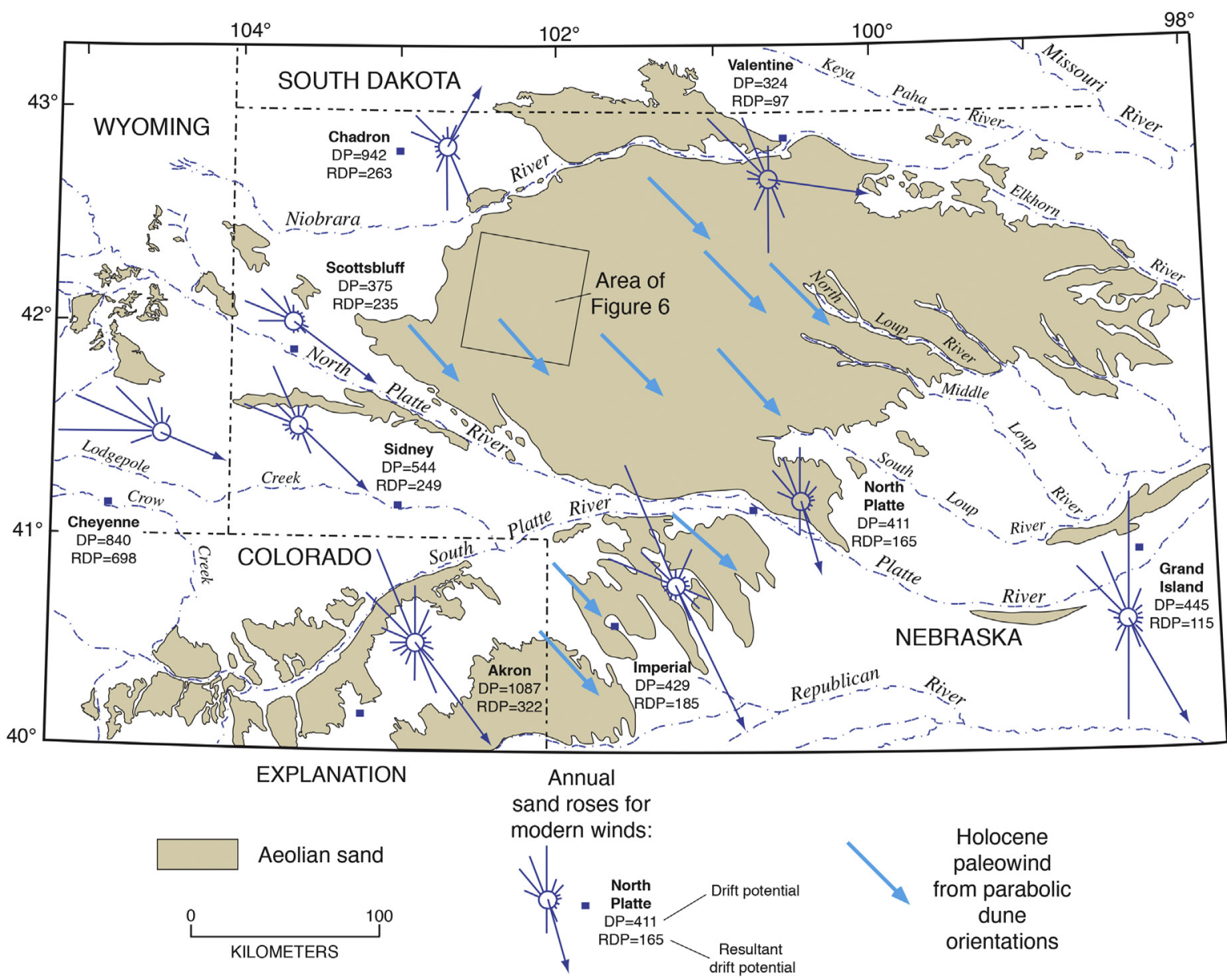

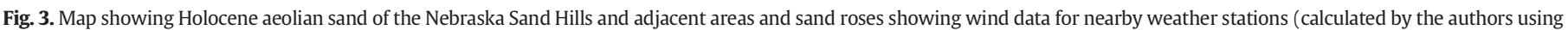

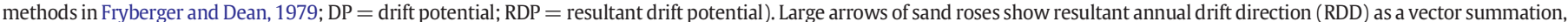

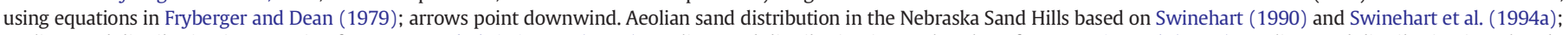

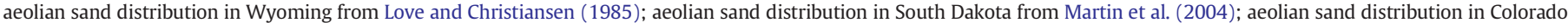

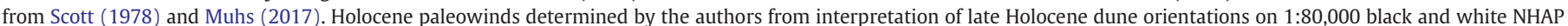

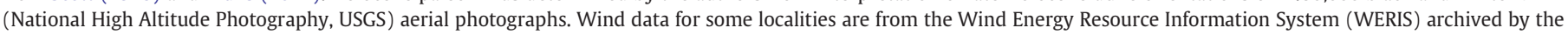

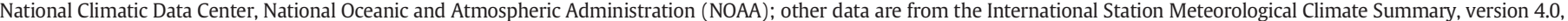
produced jointly by the U.S. Navy Fleet Numerical Meteorology and Oceanography Detachment, the National Climatic Data Center (NOAA), and U.S. Air Force USAFETAC OL-A.

measured the relative amounts of the primary minerals using X-ray diffraction (XRD) peak heights for quartz (20.9² 2-theta), K-feldspar (27.4 ${ }^{\circ}$ 2-theta), and plagioclase (27.8 2 -theta). The data for the Nebraska Sand Hills are identical to those reported by Muhs et al. (1997), but differ slightly from later analyses of the same samples in Muhs (2017). For potential source sediments, the XRD analyses of quartz, Kfeldspar, and plagioclase were done using the same methods, XRD instrument, and machine settings as those for the Nebraska Sand Hills samples given in Muhs et al. (1997). Thus, XRD data from both the Nebraska Sand Hills and potential source sediments are all directly comparable.

Concentrations of trace elements, including the REE, were determined by instrumental neutron activation analysis (INAA), following methods in Budahn and Wandless (2002). For assessment of possible aeolian sand sources, we use ratios of trace elements that have been effective in tracing origins of loess (Muhs and Budahn, 2006). These ratios utilize trace elements with a minimum degree of mobility in nearsurface environments (Taylor and McLennan, 1985; McLennan, 1989) and include Sc, Th, La, As, and Sb.

The REE are found in a broad range of minerals including pyroxenes, micas, chlorite, clay minerals, amphiboles, zircon, feldspars, and apatite (see summary tables in Taylor and McLennan, 1985). We use two sensitive indicators of REE composition, $\mathrm{La}_{\mathrm{N}} / \mathrm{Yb}_{\mathrm{N}}$, and $\mathrm{Eu} / \mathrm{Eu}^{*}$, where the "N" subscript indicates the element concentration is normalized, by convention, to chondritic meteorite values. Concentrations of REE in chondritic meteorites are considered to be representative of cosmic abundances. Normalization of REE concentrations in rocks or sediments to chondritic meteorite values effectively evens out what would otherwise be a confusing "zig-zag" pattern of absolute REE abundances. These elements are often divided into light REE (La through Sm) and heavy REE (Gd through $\mathrm{Lu}$ ) because partial melting of mantle or crustal rocks tends to cause an enrichment of the light REE over the heavy REE (McLennan, 1989). By convention, the degree of light REE enrichment over heavy REE is typically represented by a simple ratio of chondrite-normalized concentrations of $\mathrm{La}\left(\mathrm{La}_{\mathrm{N}}\right)$ to $\mathrm{Yb}\left(\mathrm{Yb}_{\mathrm{N}}\right)$. Mid-ocean ridge basalts have an average $\mathrm{La}_{\mathrm{N}} / \mathrm{Yb}_{\mathrm{N}}$ value of 0.68 , andesites have an average $\mathrm{La}_{\mathrm{N}} / \mathrm{Yb}_{\mathrm{N}}$ value of 5.8, and upper continental crust has an average $L a_{N} / Y b_{N}$ value of 9.2 (Taylor and McLennan, 1985). Thus, sediments derived from a suite of rocks with varying compositions along this continuum will have intermediate $\mathrm{La}_{\mathrm{N}} / \mathrm{Yb}_{\mathrm{N}}$ values.

The REE occur in a trivalent state under most of the pressure and temperature conditions of the Earth, but under reducing conditions (e.g., in the mantle or lower crust), Eu may occur in a divalent state (McLennan, 1989). With this charge and its ionic radius, Eu can easily substitute for $\mathrm{Sr}$, found in Ca-plagioclase, and $\mathrm{Eu}$ is also therefore enriched in Ca-plagioclase. Thus, rocks with abundant Ca-plagioclase (anorthosites) will have higher Eu concentrations relative to Sm and Gd on a chondrite-normalized REE plot, a condition referred to as a positive Eu anomaly. Rocks from the lower continental crust also have 
(a) APRIL: resultant drift potential (RDP) and resultant drift direction (RDD)

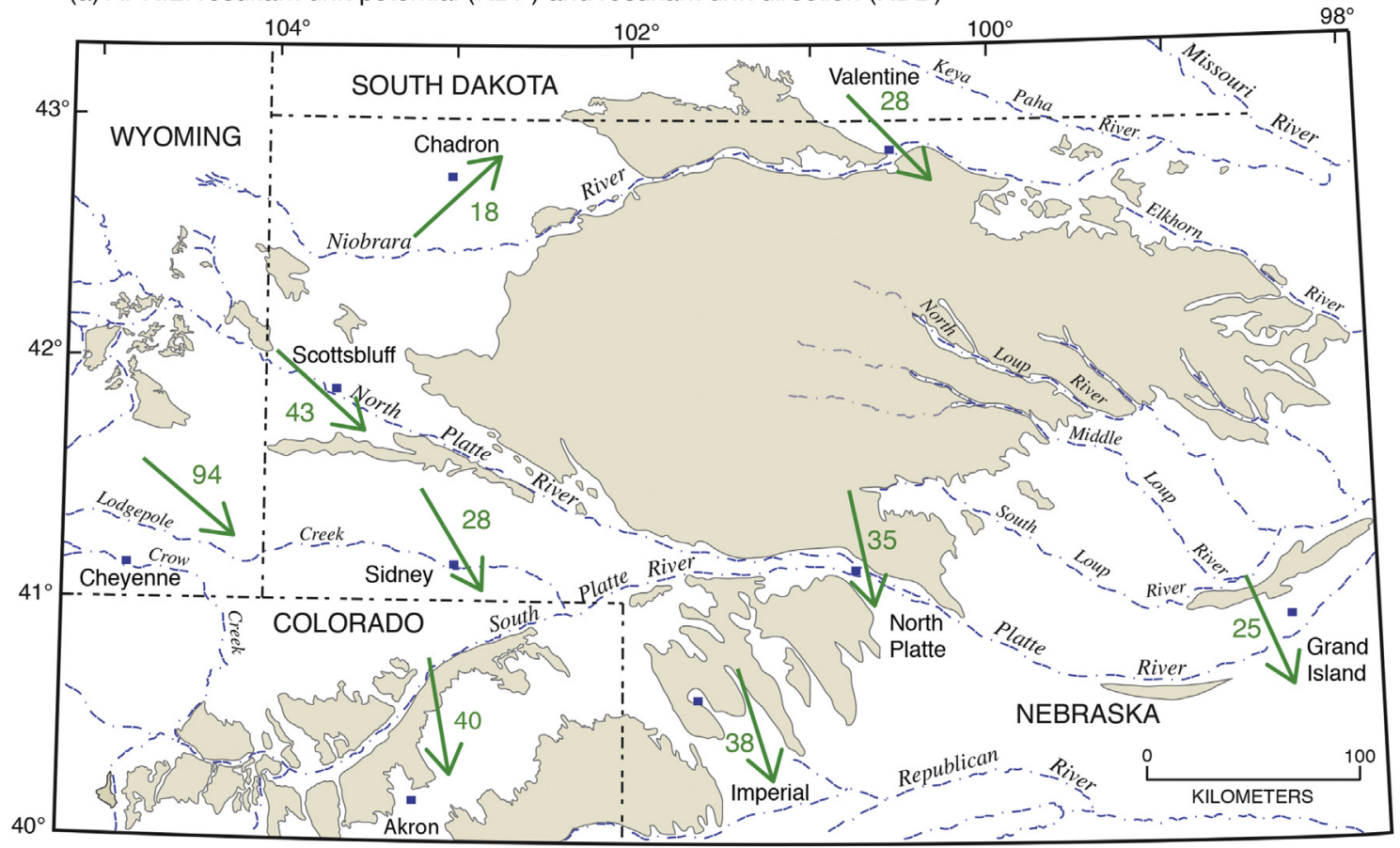

(b) AUGUST: resultant drift potential (RDP) and resultant drift direction (RDD)

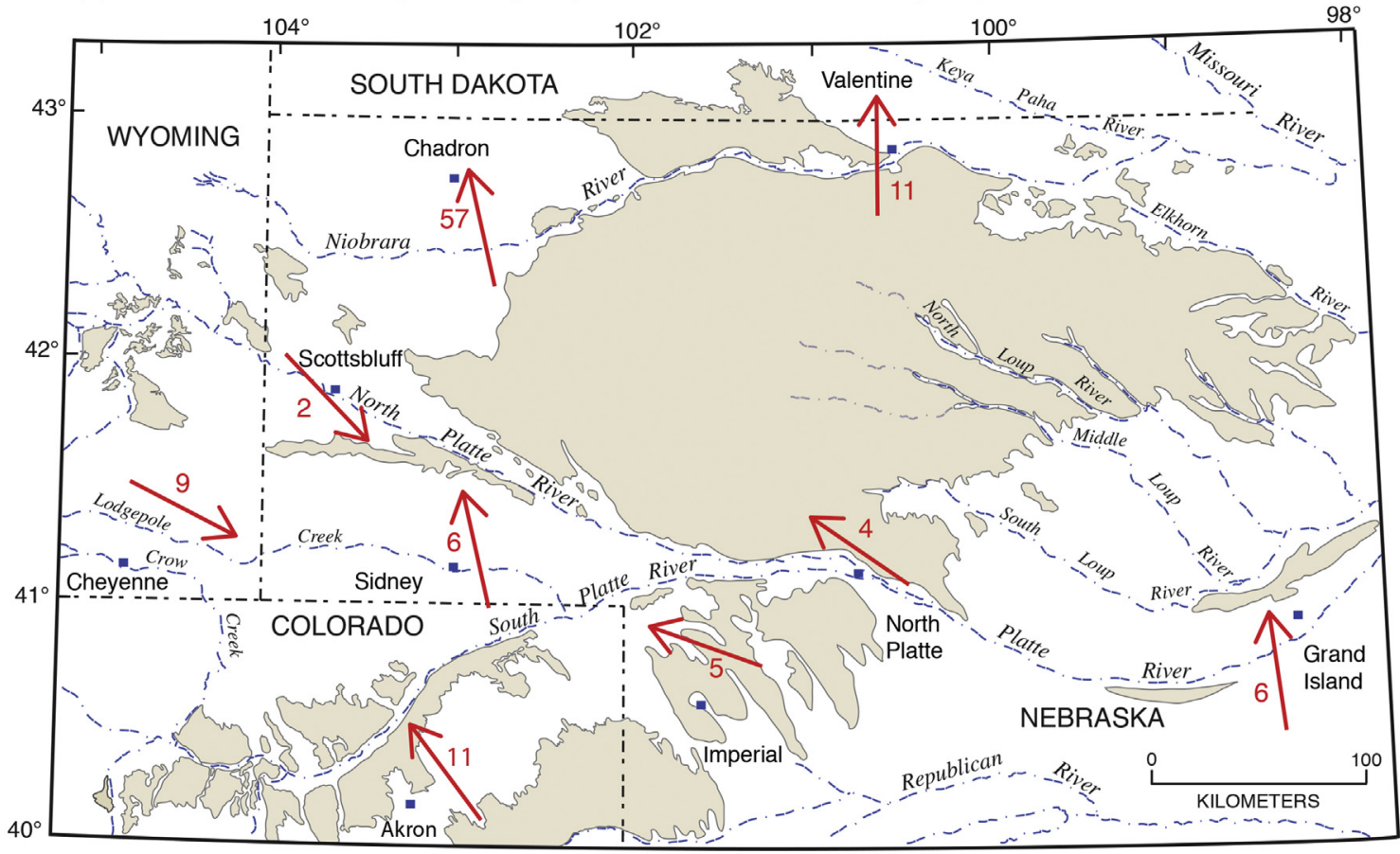

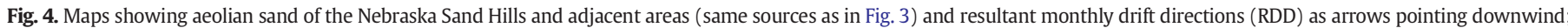

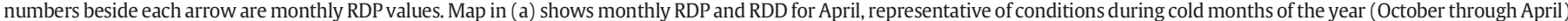

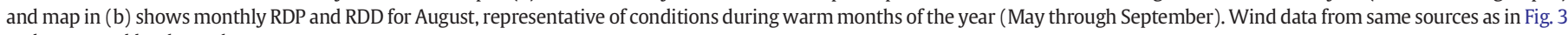
and computed by the authors.

positive Eu anomalies (Taylor and McLennan, 1985). In contrast, the upper continental crust (which has an average composition of granodiorite) is depleted in Eu, relative to Sm and Gd on a chondritenormalized REE plot, a condition referred to as a negative Eu anomaly.

The sign and degree of any Eu anomaly can be quantified by the Eu/ $\mathrm{Eu}^{*}$ value, where $\mathrm{Eu}$ is the chondrite-normalized Eu concentration $\left(\mathrm{Eu}_{\mathrm{N}}\right)$, and $\mathrm{Eu}^{*}$ is $\left(\mathrm{Sm}_{\mathrm{N}} \times \mathrm{Gd}_{\mathrm{N}}\right)^{0.5}$. Basalts that reflect a dominantly mantle origin typically have no Eu anomaly and therefore have Eu/Eu* values of 1.0 (see examples in Budahn and Schmitt, 1985). Values less than 1.0 indicate "negative" Eu anomalies; values greater than 1.0 indicate "positive" Eu anomalies. Because igneous rocks of the upper continental crust typically have negative Eu anomalies, sedimentary rocks derived from them do too, with $\mathrm{Eu} / \mathrm{Eu}^{*}$ values ranging from 0.5 to 0.6 to just under 1.0 (Taylor and McLennan, 1985; McLennan, 1989). Plots 


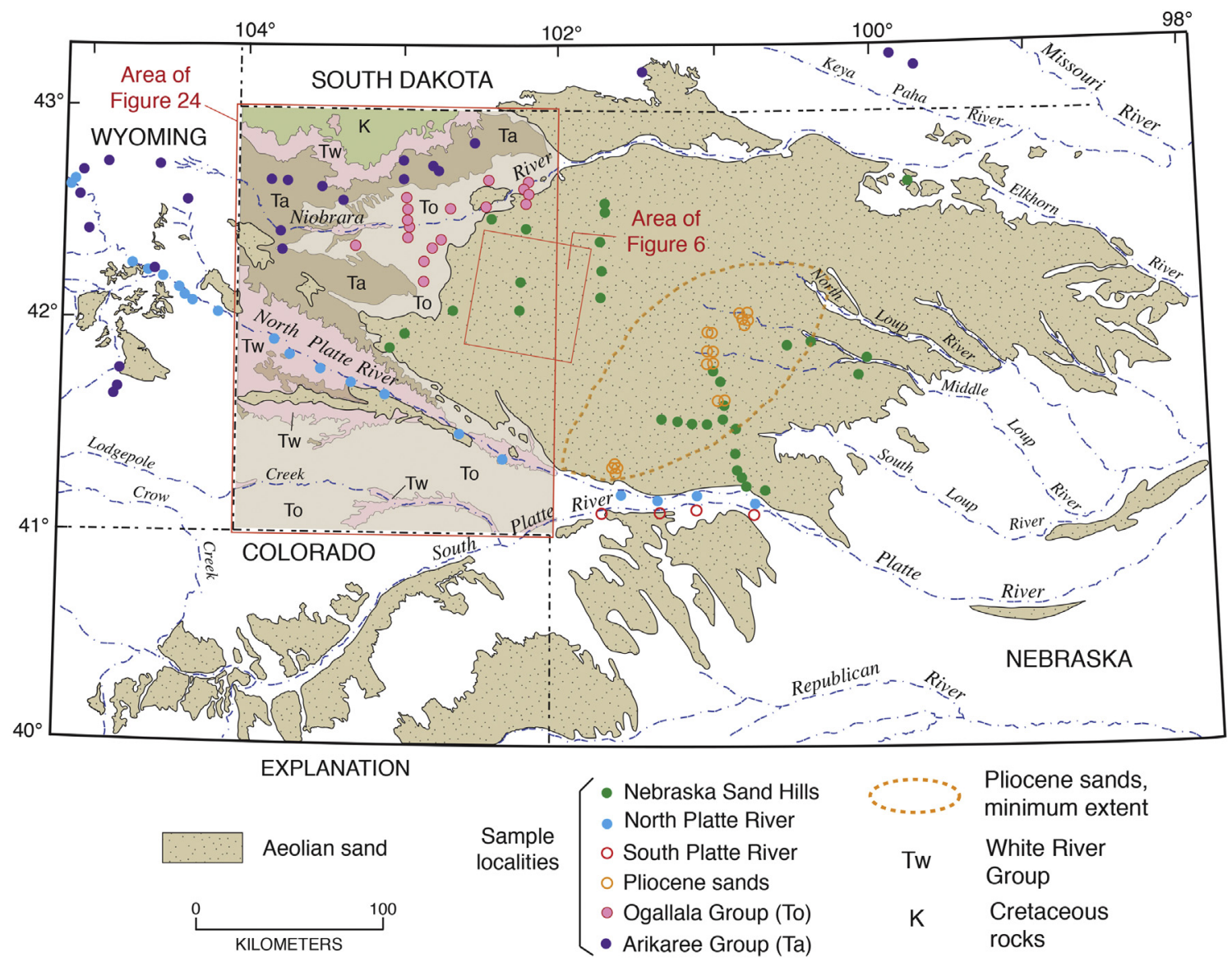

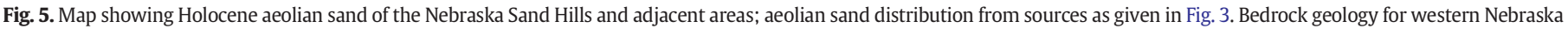

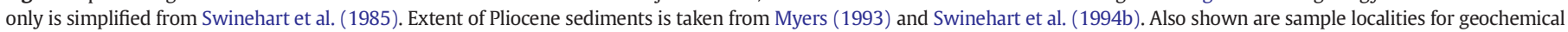
analyses conducted in the present study. Detailed coordinates and all geochemical data for all localities shown are given in Supplementary Data Table 1.

of $\mathrm{La}_{\mathrm{N}} / \mathrm{Yb}_{\mathrm{N}} \mathrm{Vs}$. Eu/Eu* are powerful tools for differentiating candidate sources of aeolian sediments (Muhs and Budahn, 2006; Sun et al., 2007; Yang et al., 2007; Liu and Yang, 2018; Muhs, 2018).

Finally, because Muhs (2017) pointed out the potential slight bias of determining $\mathrm{K}$ concentrations determined by energy-dispersive X-ray fluorescence (ED XRF), we re-determined $\mathrm{K}, \mathrm{Rb}$, and Ba concentrations in Nebraska Sand Hills samples from that study using INAA. With these new data, we recalculated $\mathrm{K} / \mathrm{Rb}$ and $\mathrm{K} / \mathrm{Ba}$ values to evaluate the earlier conclusions of Muhs (2017) based on ED XRF analyses.

\section{Results}

\subsection{Geomorphology and soils of the Nebraska Sand Hills}

The Nebraska Sand Hills host one of the richest arrays of aeolian landforms in North America. Swinehart (1990) mapped all the major types of aeolian landforms in this sand sea, including barchanoid ridges, barchans, linear dunes, parabolic dunes, dome-like dunes, and aeolian sand sheets. He further subdivided these landforms on the basis of those having low and moderate relief (sand sheets), spacing (barchans), and simple, compound, and complex forms (dome-like dunes). All these dune forms are easily visible on satellite imagery (Fig. 6) and are highlighted by the presence of interdune lakes or wetlands, which are important wildlife habitats.

Barchanoid ridges are some of the most spatially extensive dunes in the western half of the dune field. Although stabilized by vegetation, these dunes are easily recognized on aerial photographs and many are several kilometers long (Fig. 7a). The old slip faces, although degraded, are still identifiable in the field, with most dips to the southeast, indicating paleowinds from the northwest (Fig. 7b). Based on deep drilling and OSL analyses by Mason et al. (2011), it is likely that many of the barchanoid ridges were built during the last glacial period. Nevertheless, most of these large landforms are actually complex dune forms, with much smaller parabolic dunes superimposed on the barchanoid forms.

Barchan dunes occur primarily in the western part of the Nebraska Sand Hills (Swinehart, 1990). These dunes are often separated from one another by interdune lakes and wetlands, as is the case with the barchanoid ridges (Fig. 8a). Most barchans are smaller landforms, however, with many having arm-to-arm distances of $\sim 2 \mathrm{~km}$. Degraded slip faces of these dunes are also visible on aerial photographs and in the field, and like the barchanoid ridges, dip to the southeast, indicating paleowinds from the northwest (Figs. 8a,b). As with the barchanoid ridges, barchans usually host smaller, younger, parabolic dunes.

Linear dunes are dominant in the southern portion of the eastern half of the Nebraska Sand Hills (Swinehart, 1990). Such dunes are also found north of the Middle Loup River in the east-central part of the dune field, with long axes that trend northwest-southeast (Fig. 9a). Most of these dunes are $\sim 1 \mathrm{~km}$ to $\sim 3 \mathrm{~km}$ in length, but dunes up to $\sim 5 \mathrm{~km}$ long are also found. Cross-beds with dips to the southwest are sometimes exposed in blowouts, such as those in a northwestsoutheast-trending linear dune arm northeast of the town of Dunning (Fig. 9b). Sridhar et al. (2006) proposed that these dunes were built during the Medieval Warm Period, 800 to $1000 \mathrm{yr}$ ago, when moist air flow from the southeast in spring and summer was replaced by dry air from the southwest, bringing about drought conditions.

Finally, parabolic dunes are found extensively over the Nebraska Sand Hills (Fig. 10). Swinehart (1990) mapped this dune type as the 


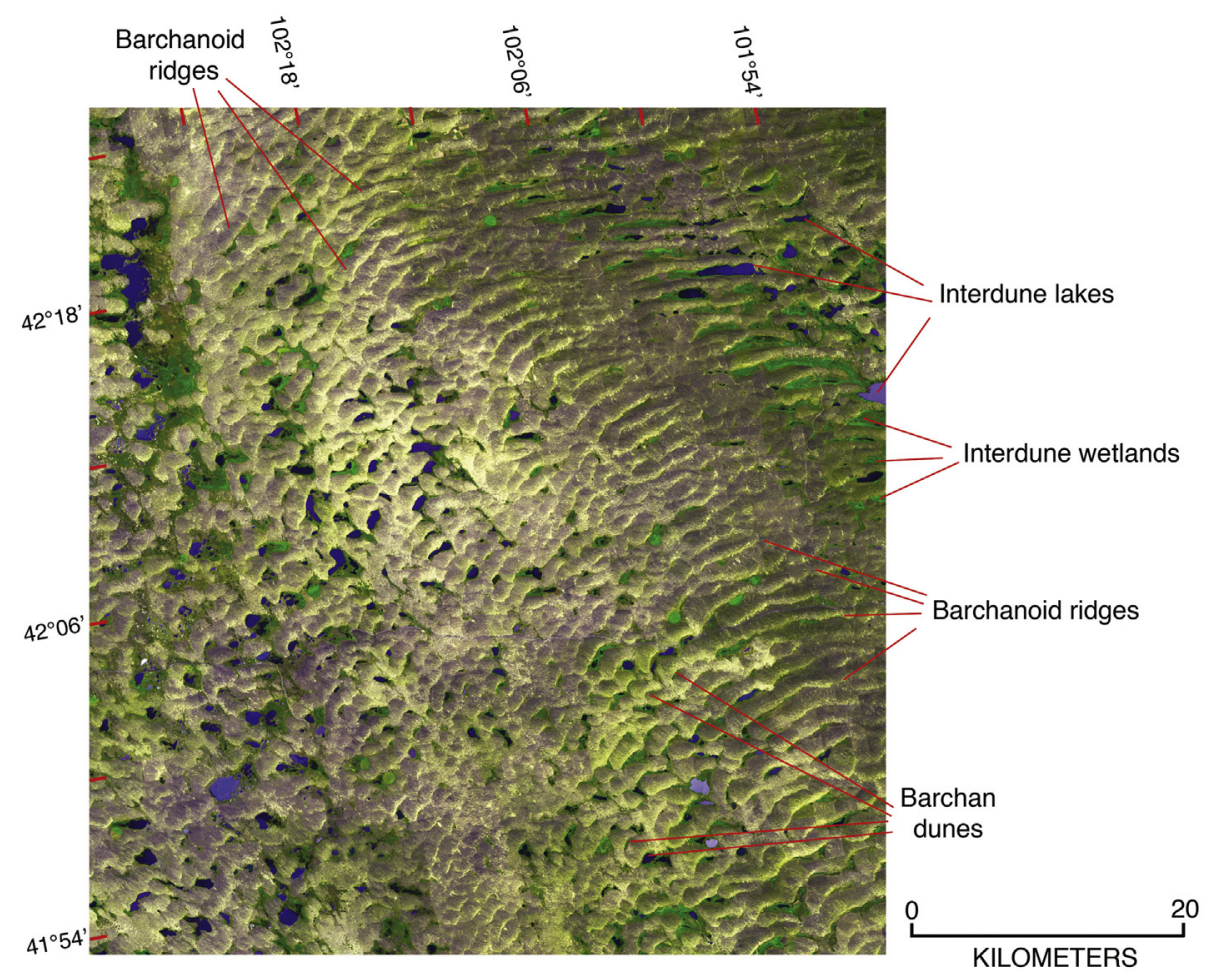

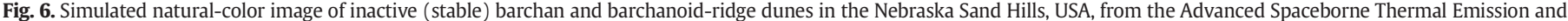
Reflection Radiometer (ASTER) on NASA's Terra satellite, acquired 10 September 2001[image courtesy NASA/GSFC/METI/ERSDAC/JAROS and U. S./Japan ASTER Science Team].

dominant landform in the southwestern part of the region. As described above, however, small, younger parabolic dunes are superimposed on the much larger barchans or barchanoid ridges, forming complex dunes. Virtually all of the parabolic dunes that we have observed have noses that point to the southeast and arms that point to the northwest, indicating formation under dominantly northwesterly winds.

Despite their simple morphology and young ages, parabolic dunes of the Nebraska Sand Hills host a diverse suite of primary and secondary structures. Paleosols, typically with A/AC/C profiles, are common, indicating multiple cycles of aeolian sand activity and stability during the late Holocene (Figs. 11a, b). Although cross-bedding is exposed in some parabolic dunes, horizontal or low-angle, pin-stripe ripple strata can also be observed (Figs. 11c, d), indicating the likelihood of some aeolian sediment being deposited as sheet sands (Fryberger and Schenk, 1988). Both cross-bedded sands and horizontal pin-stripe laminations often have been deformed by prehistoric bison, first noted by Loope (1986). Bison hoof prints often show impressive preservation in both cross section and plan view, even though the host sands are young and unconsolidated (Fig. 11e).

In northeastern Colorado, where aeolian sand is also extensive (Figs. 2-5), radiocarbon and luminescence ages indicate that there are both late Pleistocene dunes or sand sheets and late Holocene dunes (Madole, 1995; Muhs et al., 1996; Clarke and Rendell, 2003; Madole et al., 2005; Berry et al., 2015). These studies have shown that aeolian sands dating to the late Pleistocene, specifically the last glacial period, host soils with $\mathrm{A} / \mathrm{Bt} / \mathrm{Bk} / \mathrm{C}$ profiles. In contrast, aeolian sands dating to the late Holocene host soils with only simple $\mathrm{A} / \mathrm{AC} / \mathrm{C}$ profiles. In the $\mathrm{Ne}-$ braska Sand Hills, soils developed in aeolian sand or in alluvium derived from aeolian sand are all minimally developed, with $\mathrm{A} / \mathrm{AC} / \mathrm{C}$ profiles (Fig. 12). The implications of this soil geography are quite profound. Minimally developed soils over the entire Nebraska Sand Hills region implies that there has been aeolian activity of late Holocene age virtually everywhere in this sand sea, though all dunes were not necessarily active at the same time. All Nebraska Sand Hills samples we collected were from localities with $\mathrm{A} / \mathrm{AC} / \mathrm{C}$ profiles, indicating late Holocene ages.

\subsection{Geology and geomorphic setting of potential source sediments}

To consider sediments to be potential sources for the Nebraska Sand Hills, they must meet several requirements. Because the Nebraska Sand Hills are composed of fairly well sorted sands composed of primary rock-forming minerals (quartz and feldspars), potential source sediments must have a favorable particle-size distribution and mineralogy. This eliminates fine-grained sedimentary rocks in the Great Plains region such as the Cretaceous Pierre Shale (clay-mineral-dominated) and the Oligocene White River Group (silt-dominated), but sanddominated units such as the Arikaree Group (Oligocene-Miocene) and Ogallala Group (Miocene) are suitable candidates. Younger, sand-rich sediments are also potential sources, including Pliocene sands that underlie the Nebraska Sand Hills and sandy point bars of major rivers. A second requirement is that a potential source must be in a geographically favorable position, either upwind of the Nebraska Sand Hills or at least formerly upwind if it is now buried beneath the dune field. Sediments of the Arikaree Group and Ogallala Group are exposed at the surface to the northwest of the dune field and are therefore candidate source sediments when winds are from the northwest, during the period from October through April (Fig. 4a). The Niobrara River, which drains these two sediment groups, is also situated to the northwest of most of the Nebraska Sand Hills (Figs. 3 and 5). Pliocene sediments are found beneath the Nebraska Sand Hills mostly in the south-central part of the dune field, and the North Platte, South Platte, and Platte Rivers are found to the west, southwest, south, and southeast of the dune field. Thus, these younger sediments are potentially important sources of aeolian sand if transport occurred during the warmer months of the year, May through September (Fig. 4b). Finally, potential source sediments must be unconsolidated and exposed at the surface, or if partially consolidated, a landscape with a potential source rock must be dissected to the extent that loose particles are available for aeolian entrainment. Here we report field observations of the Arikaree Group, Ogallala Group, Pliocene sediments and North Platte River sediments in light of these requirements. 

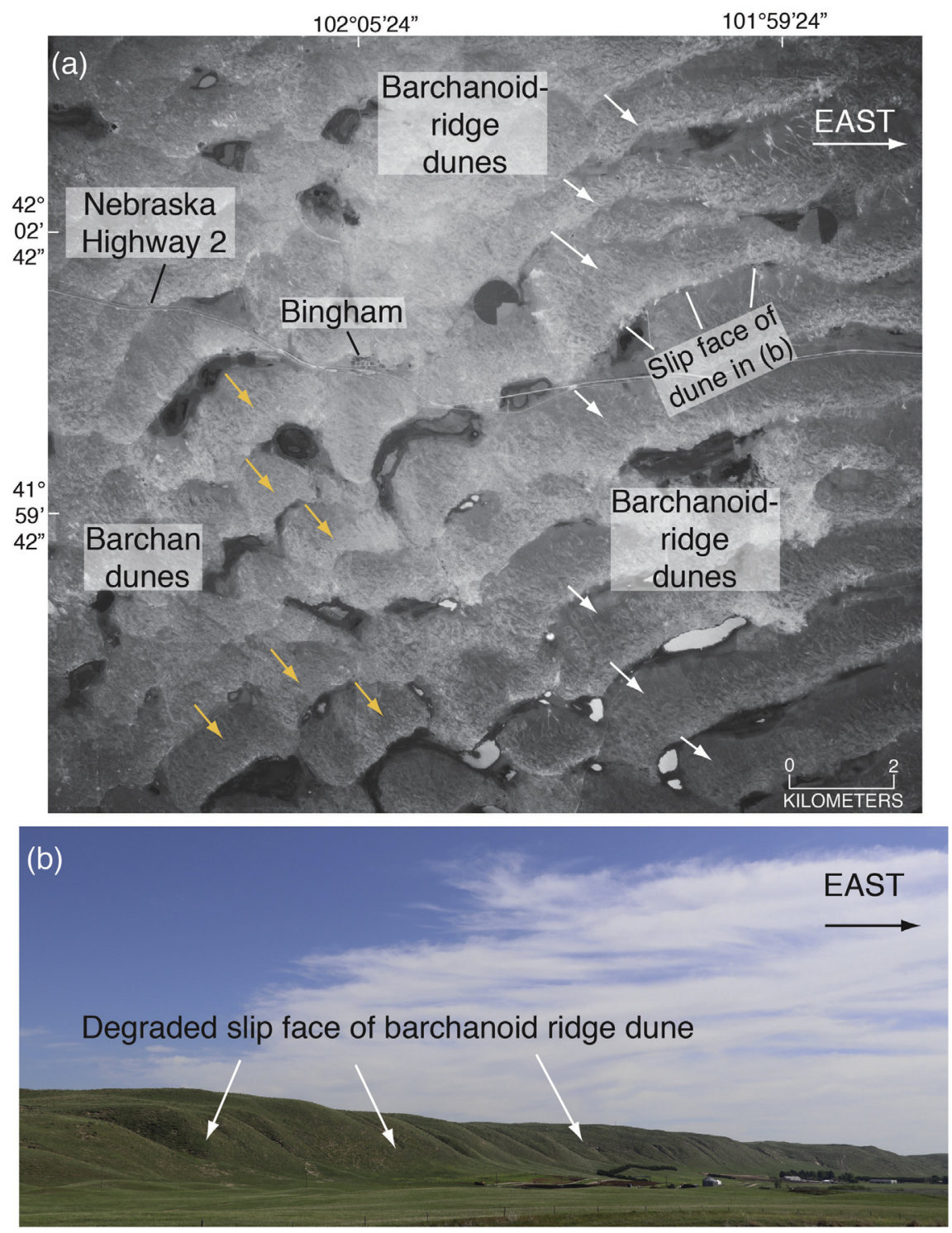

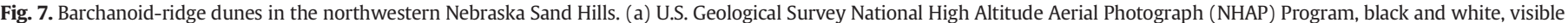

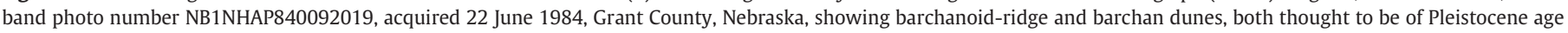

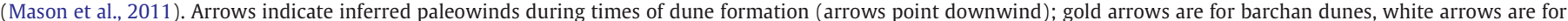

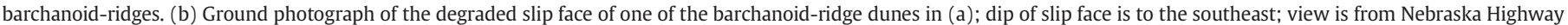
2 at $N 42^{\circ} 01.049^{\prime}, \mathrm{W} 102^{\circ} 02.130^{\prime}$. Photo in (b) by D.R. Muhs.

The Arikaree Group is exposed at the surface over a large area of eastern Wyoming (Love and Christiansen, 1985), and smaller but stillextensive areas of South Dakota (Martin et al., 2004), and Nebraska (Fig. 13). Most of these surface occurrences are situated to the northwest of the Nebraska Sand Hills. The Arikaree Group is primarily unconsolidated sands and sandstone, but includes some silty beds (Swinehart and Loope, 1987; MacFadden and Hunt Jr., 1998). Where the Arikaree Group crops out in northwestern Nebraska, it forms the substrate for the scenic Pine Ridge area, an unusual and isolated occurrence of Pinus ponderosa, more commonly found at higher elevations in the Rocky Mountains. The landscapes dominated by the Arikaree Group are broad, flat tablelands (Fig. 13a). These mesa-like landscapes are, however, dissected by first-order and second-order streams that deliver sediment eroded from the Arikaree Group to major river systems such as the White River, Niobrara River, and North Platte River. Examination of road cuts and stream cuts exposing the Arikaree Group shows that although some units are cemented (hence forming the resistant tableland landscapes), other units are unconsolidated (Fig. 13b). Rhizoliths, faunal burrows, and other secondary structures are also common within sediments of the Arikaree Group (Fig. 13c).

The Ogallala Group is spatially the most extensive pre-Quaternary geologic unit in central and western Nebraska (Burchett, 1969). As with the Arikaree Group, resistant, well-cemented beds within the Ogallala Group form extensive mesas at the surface over large areas of western Nebraska, eastern Wyoming, and eastern Colorado (Fig. 14a). Similar to the Arikaree Group, however, these tableland areas are dissected by first-order and second-order streams that deliver sediment to much larger drainage systems. The Ogallala Group is also found below the Nebraska Sand Hills, based on drill-hole data (Swinehart and Diffendal Jr., 1990). The youngest and most widespread unit within the Ogallala Group is the Ash Hollow Formation. This formation is also one of the thickest units within the Ogallala Group and is $\sim 50 \mathrm{~m}$ thick in its type area (Diffendal Jr., 1987). Road cut and stream cut exposures show that the Ash Hollow Formation of the Ogallala Group consists of sediments with highly variable particle sizes (Diffendal Jr., 1987), ranging from silty volcanic ash beds to gravels (Fig. 14b). Paleosols, including 

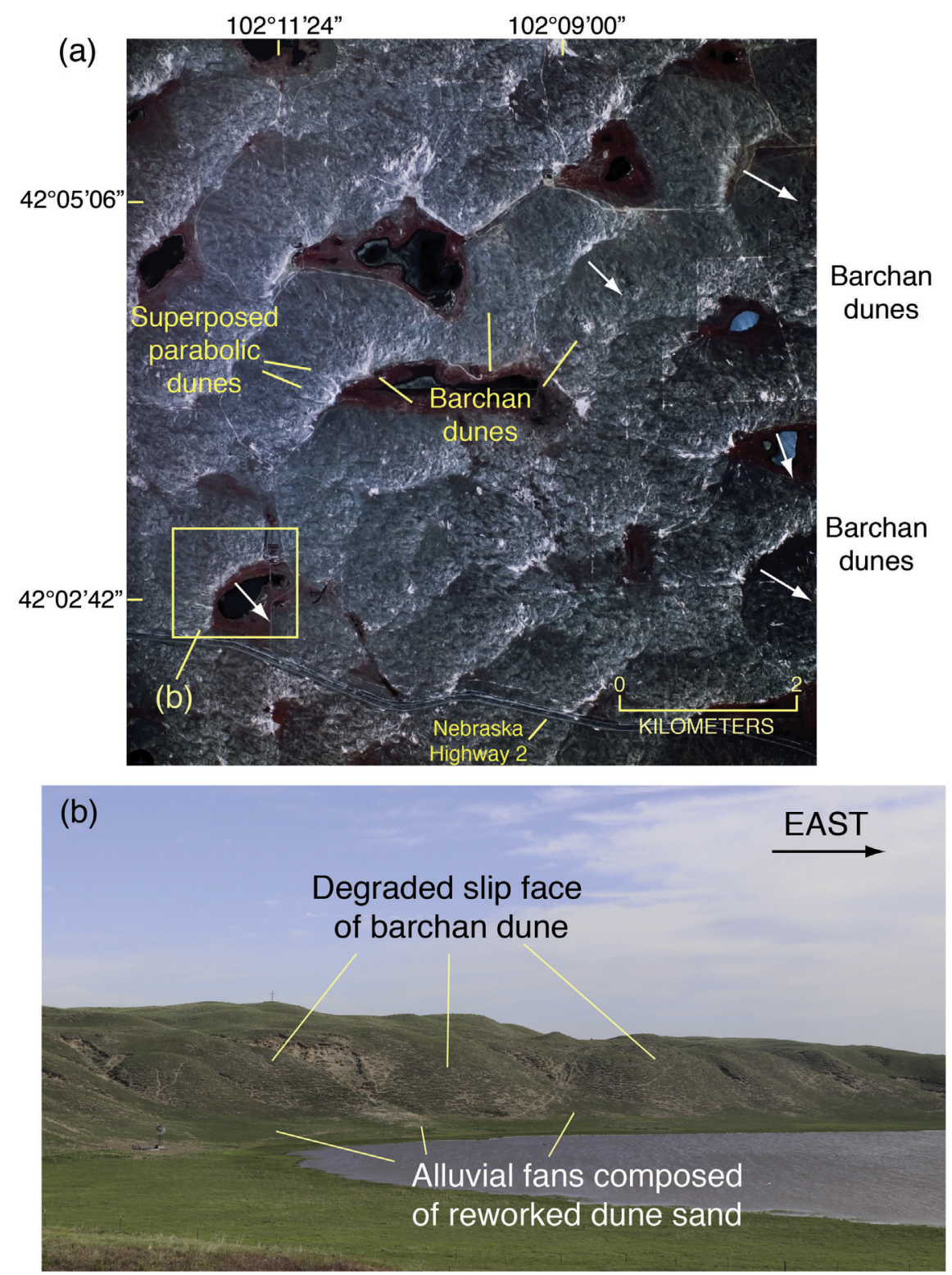

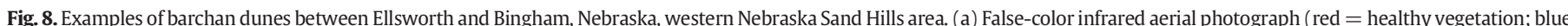

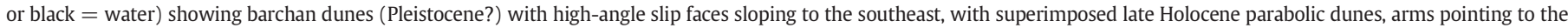

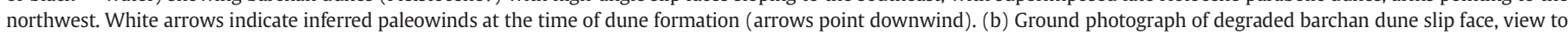

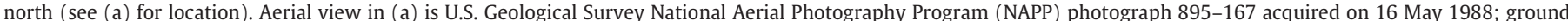
photography in (b) taken by D.R. Muhs.

very resistant calcrete layers ( $\mathrm{K}$ horizons) are also visible in many outcrops of the Ogallala Group (Fig. 14c). However, much Ogallala Group sediment found between paleosols is unconsolidated sand and provides sediment delivered to first-order and second-order stream valleys west of the Nebraska Sand Hills.

Pliocene sediments, some of which are part of the Broadwater Formation in western Nebraska (Swinehart and Diffendal Jr., 1987), are found below and to the west of the Nebraska Sand Hills. Swinehart and Diffendal Jr. (1990), Myers (1993), and Swinehart et al. (1994b) reported a minimum extent of these deposits found beneath the Nebraska Sand Hills (Fig. 5). Along the Middle Loup River, we measured as much as $\sim 28 \mathrm{~m}$ of these sediments exposed in river cuts (Fig. 15), underlying 11-12 $\mathrm{m}$ of aeolian sand dated by Muhs et al. (1997) to the late Holocene. The Pliocene sands here are horizontally bedded, very poorly consolidated or entirely loose, silt-rich in the younger parts, and sand-rich in the older parts.
Under favorable circumstances, major river valleys can be sources of aeolian sand and there are numerous examples of these from both the Great Plains and Basin and Range regions of the USA. There are several river systems adjacent to the Nebraska Sands Hills. The most important of these is the Platte River with its two major tributaries, the North Platte River and the South Platte River. Both of these tributaries head in the mountains of Colorado, but while the downstream reaches of the South Platte River are in eastern Colorado and southwestern Nebraska, the North Platte River drains much of eastern Wyoming and western Nebraska. All three rivers (North Platte, South Platte, and Platte) have, at present, fairly narrow channels with perennial flow and floodplains and channel bars that are largely vegetated. Williams (1978) has shown, however, that the perennial conditions of these rivers, along with their channel morphology and vegetated bars and floodplains, are a function of historical river regulation. Prior to regulation, these rivers experienced high-discharge events during the spring 
(a)

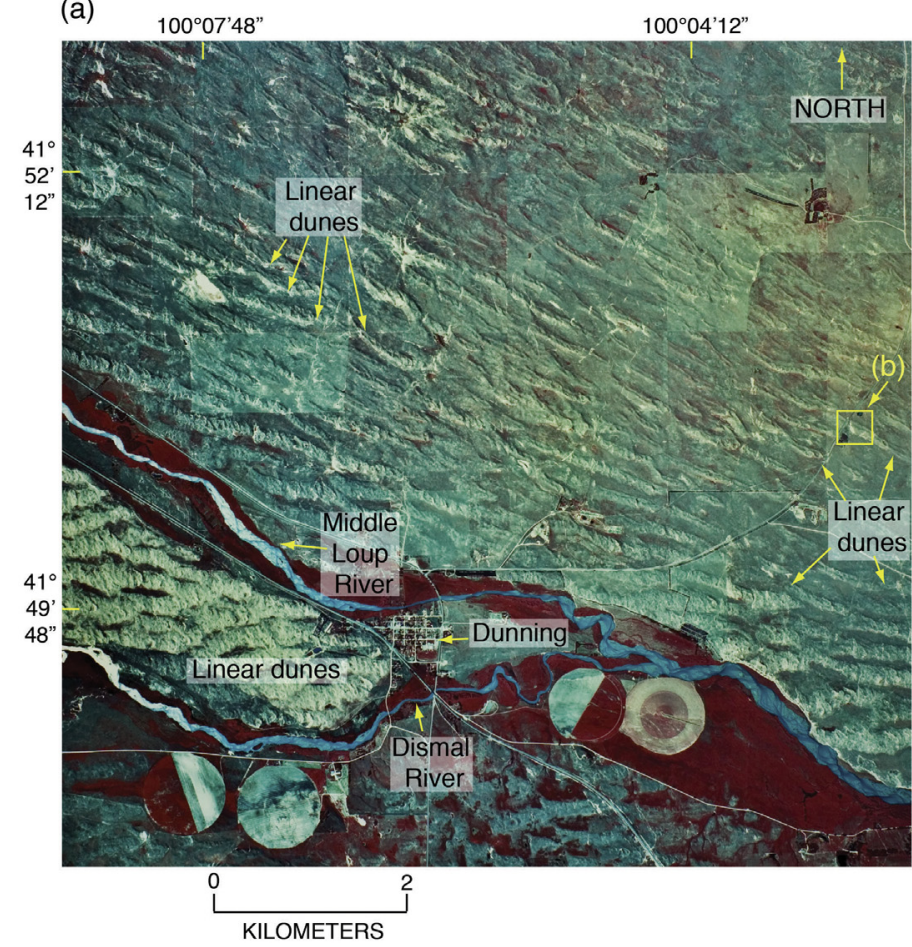

(b)

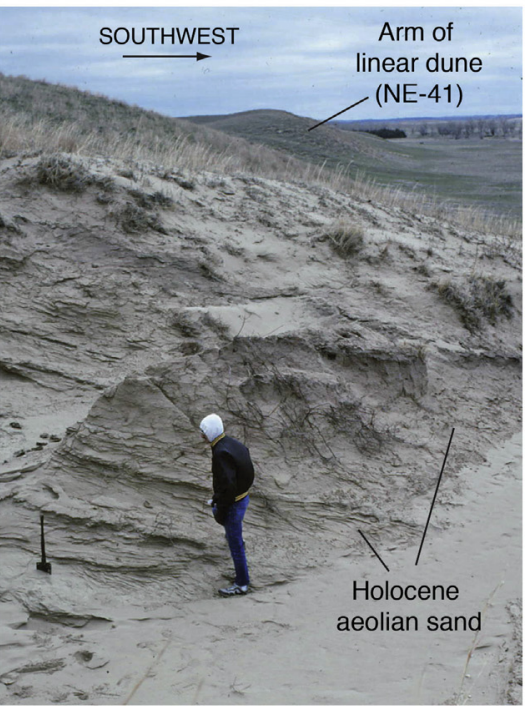

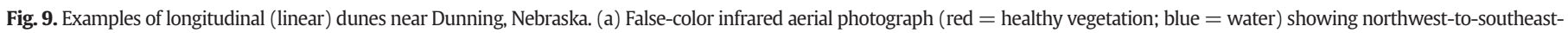

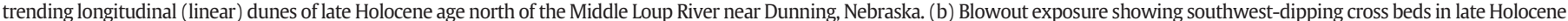

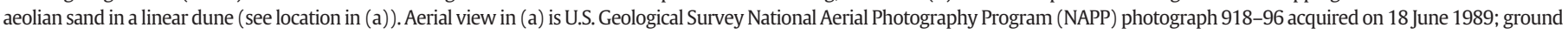
photography in (b) taken by D.R. Muhs.

snowmelt season that removed much of the vegetation that could have potentially stabilized sandy point bars. Furthermore, at the end of summers in the pre-regulation era, discharge in all three rivers was usually diminished substantially; the rivers were intermittent, not perennial. As a consequence, channel morphology was of a braided nature, with abundant sandy, unvegetated point bars. It is likely that many channels

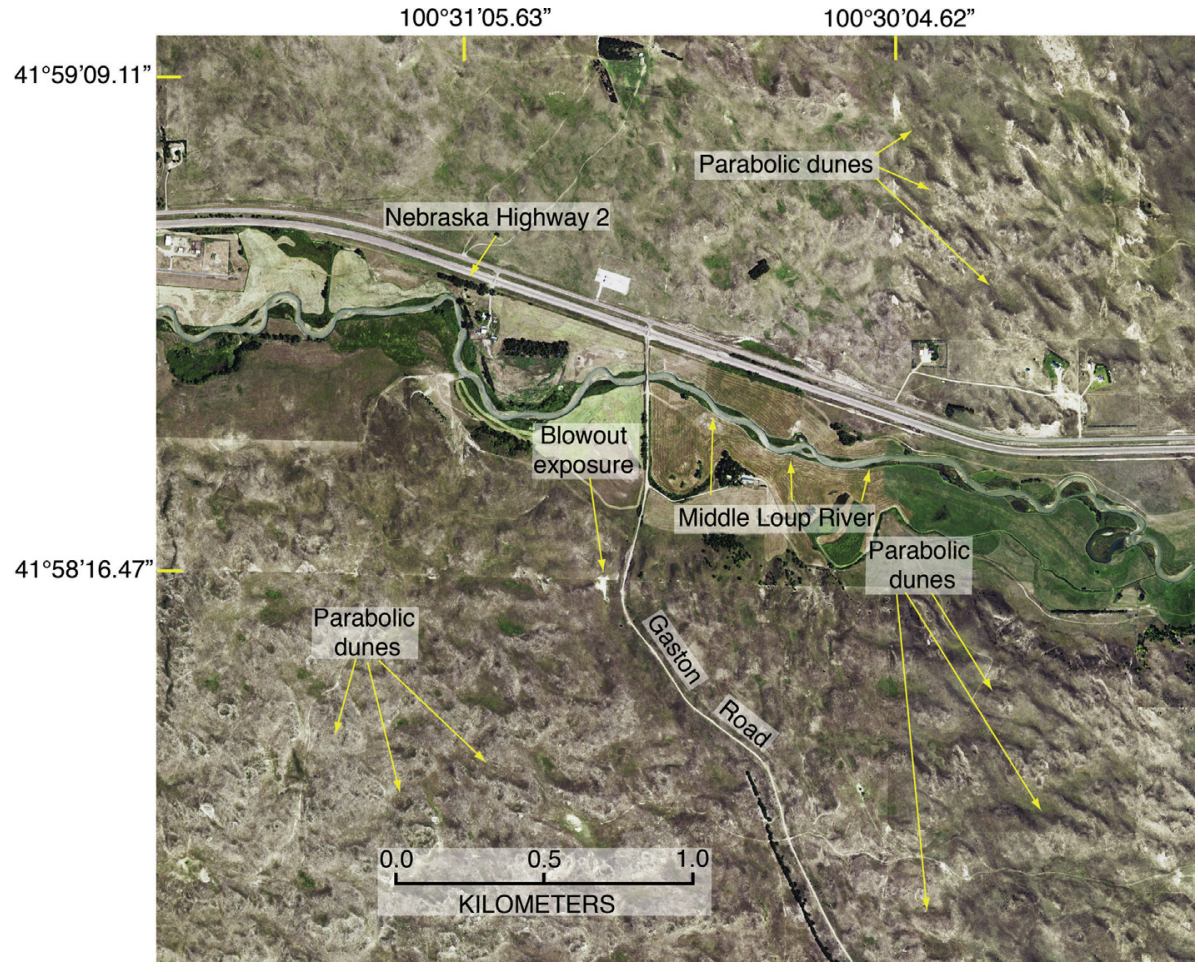

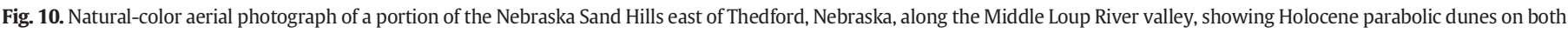

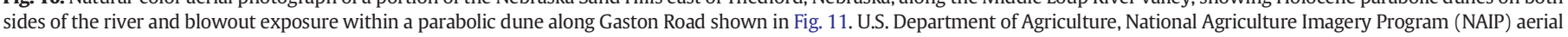
photograph. 

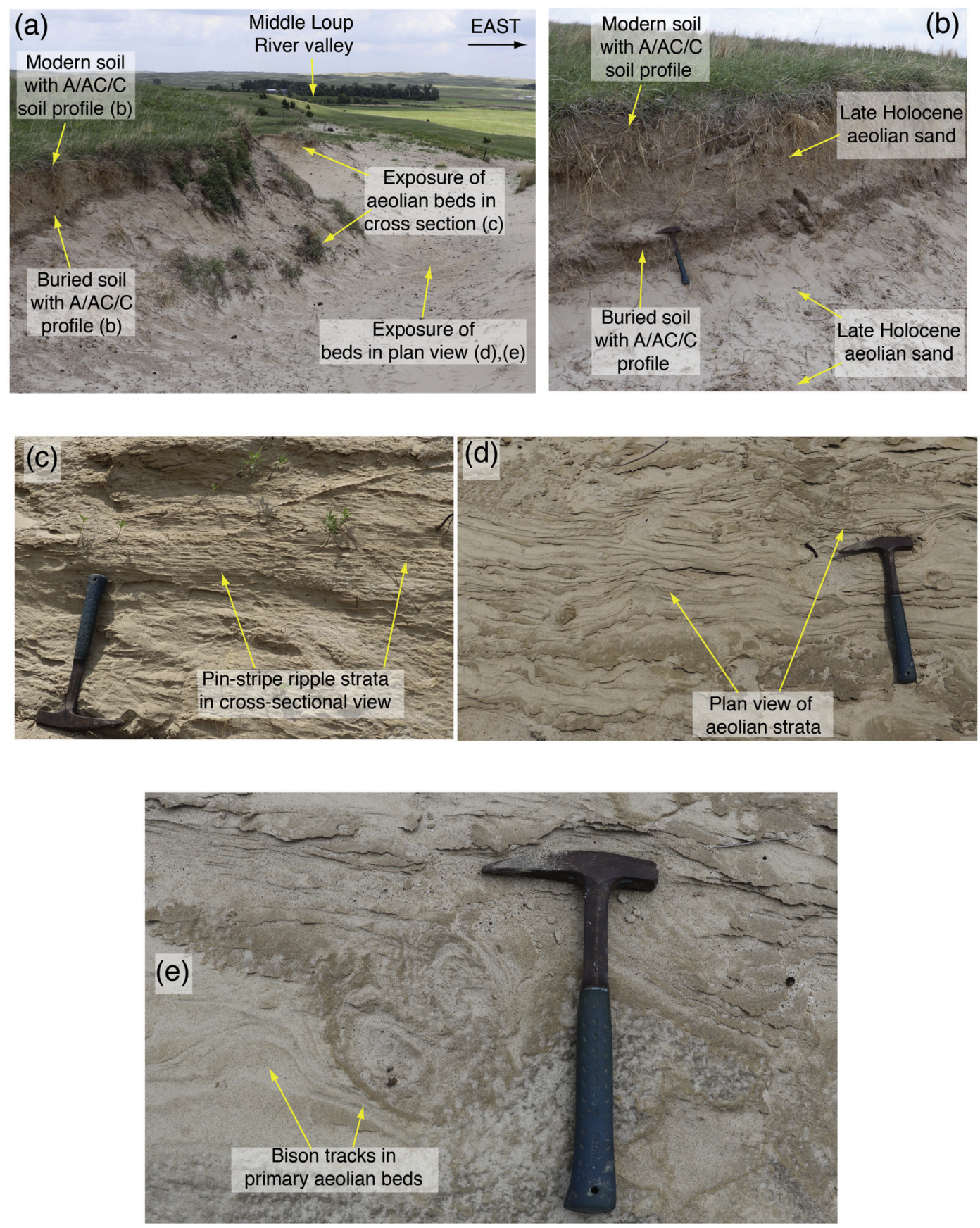

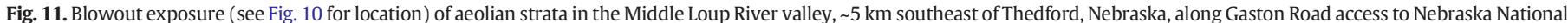

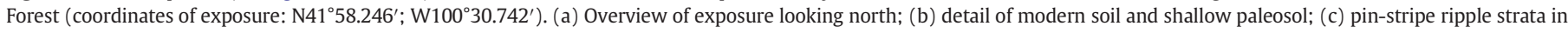

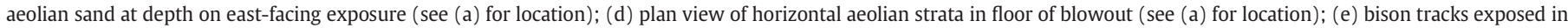
primary aeolian strata in floor of blowout. Hammer in all photos is $\sim 0.3 \mathrm{~m}$ long. Photos by D.R. Muhs.

were even dry during late summer, fall, and early winter of some years. Construction of dams and reservoirs in historical time, as well as return flow from irrigation canals, brought about perennial flow; creation of deeper, narrower channels (without a braided morphology); and a decrease in discharge magnitude during the spring snowmelt season. As a consequence, channel bars and floodplains became more vegetated. Muhs and Holliday (1995) pointed out that contemporary, postregulation conditions are not particularly favorable to the Platte River system being a significant source of aeolian sand. However, in preregulation time, rivers with broad valleys, shallow braided channels, and abundant, unvegetated sandy bars were ideal for providing an abundant source of aeolian sand (Fig. 16). We focused most of our efforts on characterizing fine-grained sands from the North Platte River, with some exploratory characterization of sands from the reaches of the South Platte River within Nebraska.

The Niobrara River valley is situated to the west and north of most of the Nebraska Sand Hills and is a candidate source as well (Fig. 3). In its downstream reaches, to the north of the Nebraska Sand Hills, the Niobrara River occupies a narrow, deep channel cut into bedrock, conditions that are not particularly favorable for providing a source of sand for dunes. In its upstream reaches, west of the Nebraska Sand Hills, the Niobrara River occupies a broader valley, but drains only the Arikaree Group and Ogallala Group, from its headwaters in eastern Wyoming to where it enters the dune field in Nebraska (Burchett, 1969; Love and Christiansen, 


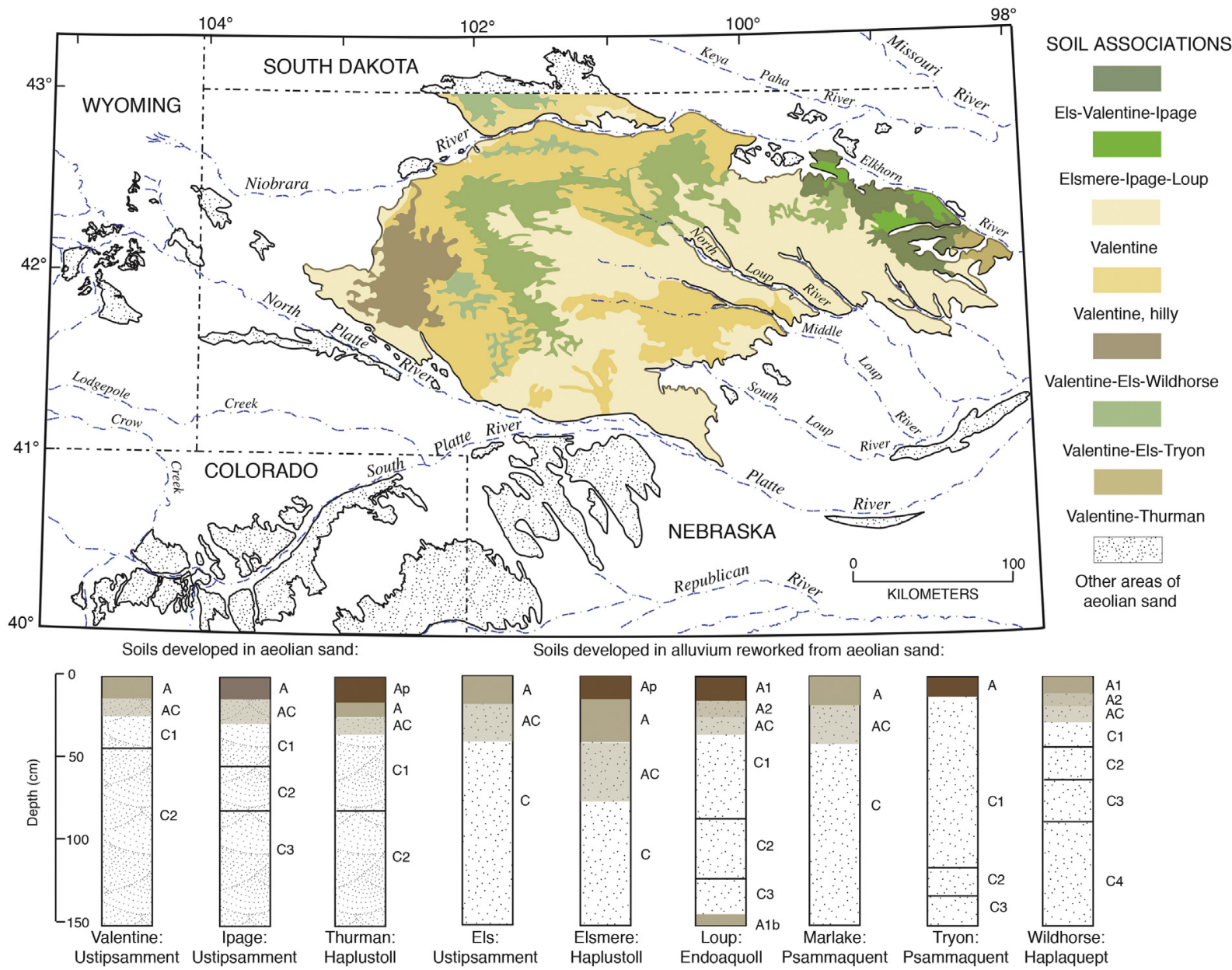

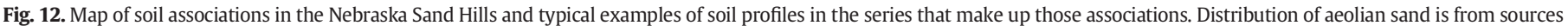
given in Fig. 3; soil association distribution and representative soil profiles are from Kuzila (1990).

1985). Thus, the composition of Niobrara River sediments in its headwaters is likely a mix of Arikaree Group and Ogallala Group sediments.

\subsection{Mineralogy of the Nebraska Sand Hills}

In order for a sediment group to be considered as a source for the Nebraska Sand Hills, it must have a favorable mineralogy. Ahlbrandt and Fryberger (1980), Winspear and Pye (1996), Muhs et al. (1997), and Muhs (2017) present mineralogical data for the Nebraska Sand Hills. All these studies are in broad agreement with one another and show that the dominant minerals are quartz, K-feldspar, and plagioclase. We have found no substantial amounts of calcite or dolomite in the Nebraska Sand Hills nor have other investigators reported carbonate minerals. Using point counts in thin sections, quartz contents of the Nebraska Sand Hills are estimated to be $50-75 \%(n=7)$ by Ahlbrandt and Fryberger (1980) and $75-85 \%(n=6)$ by Winspear and Pye (1996). Based on calibrated abundances using mineral XRD peak heights, Muhs (2017) estimated quartz contents to be $45-85 \%$ ( $n=$ 55 ), with two samples having less than $40 \%$ quartz. K-feldspar content is estimated to be $5-29 \%$, with most samples ranging from 5 to $15 \%$, and plagioclase is estimated to be $10-67 \%$, with most samples ranging from 12 to 36\% (Muhs, 2017). Heavy minerals are present in small amounts in the Nebraska Sand Hills and include muscovite, amphiboles, and pyroxenes, with smaller amounts of biotite, epidote, zircon, and tourmaline (Lewis, 1976).

To facilitate comparisons of Nebraska Sand Hills dune sands with those of potential source sediments, we present relative abundances of quartz, K-feldspar, and plagioclase of dune sands and source sediments as ternary plots using XRD peak heights. We emphasize that these plots do not represent precise measures of mineral percentages, but merely provide a graphical presentation of relative differences between the sediment groups in an analytically consistent way. Results indicate that with the exception of two low-quartz samples, Nebraska Sand Hills samples define a compositional field similar to that reported by Muhs (2017), with most samples falling close to the quartz pole (Fig. 17). All four source sediments examined also contain quartz, Kfeldspar, and plagioclase. Sands from the Arikaree Group show a much wider range in quartz and plagioclase contents and have only partial overlap with Nebraska Sand Hills sands. North Platte River sands also have only a partial overlap with Nebraska Sand Hills sands, as most of the latter are more quartz rich. In contrast, Pliocene sands and sands from the Ogallala Group define mineralogical compositional fields that overlap that of the Nebraska Sand Hills fairly closely.

\subsection{Trace element geochemistry of the Nebraska Sand Hills and potential source sediments}

In utilizing $\mathrm{K} / \mathrm{Rb}$ vs. $\mathrm{K} / \mathrm{Ba}$ values to determine dune sand sources (including the Nebraska Sand Hills) for many parts of North America, Muhs (2017) noted that determinations of K concentrations by energydispersive X-ray fluorescence (ED XRF) can be biased high by 5\% of the reported concentration, based on analyses of U.S. Geological Survey rock standards (Govindaraju, 1989) and comparison with K concentrations determined by wavelength-dispersive XRF. Hence, we re-determined $\mathrm{K}, \mathrm{Rb}$, and Ba concentrations by INAA for samples from the Nebraska Sand Hills and compared the results to values for the same samples determined by 


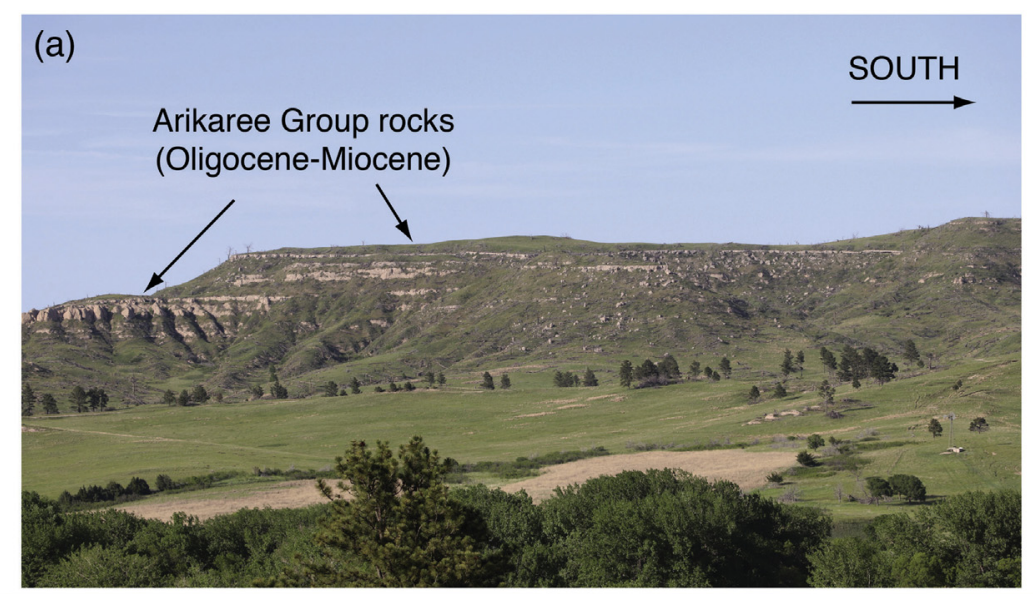

Rhizoliths

and/or

burrows
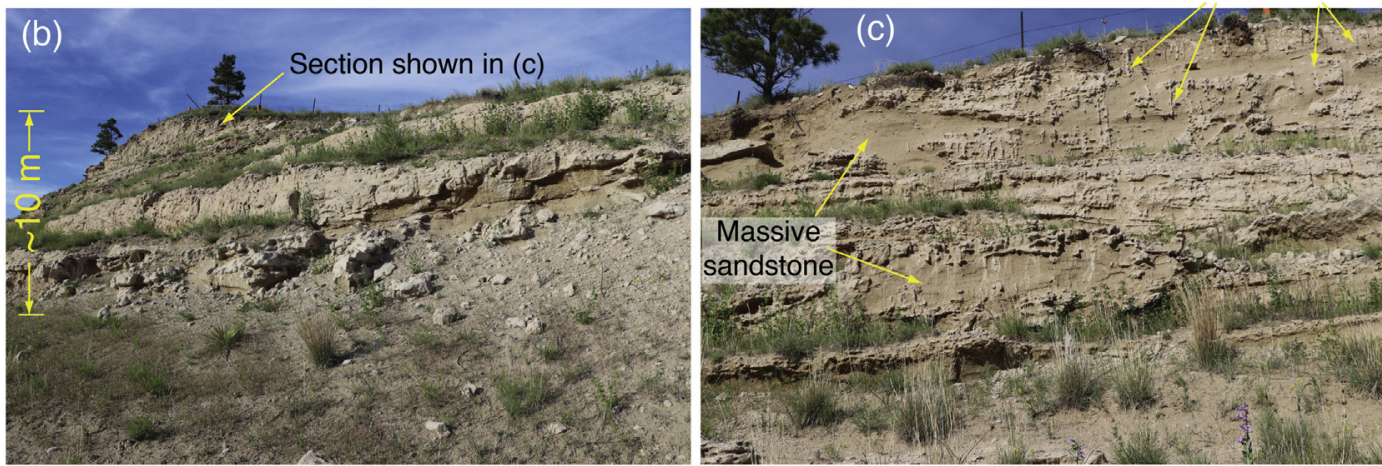

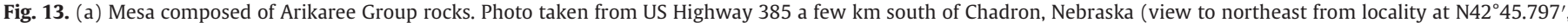

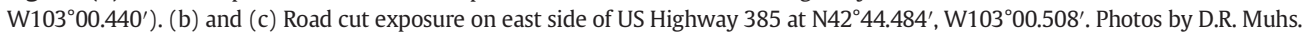

ED XRF reported by Muhs (2017). Results indicate that both Rb and Ba show good agreement between the two methods, but as noted by Muhs (2017), K concentrations determined by ED XRF are higher than those determined by INAA. Thus, we recalculated $\mathrm{K} / \mathrm{Rb}$ and $\mathrm{K} / \mathrm{Ba}$ values for $\mathrm{Ne}-$ braska Sand Hills samples and potential source sediments as a further test of the interpretations made by Muhs (2017).

Results of the new $\mathrm{K} / \mathrm{Rb}$ and $\mathrm{K} / \mathrm{Ba}$ analyses show that potential source sediments define geochemical fields similar to those shown in Muhs (2017). With the lower K concentrations determined by INAA, all $\mathrm{K} / \mathrm{Rb}$ and $\mathrm{K} / \mathrm{Ba}$ values are of course systematically lower. Nevertheless, the geochemical fields defined by these elements have the same general form as those determined by ED XRF. With the exception of one dune sand sample with anomalously low K concentrations (which we have no explanation for), Nebraska Sand Hills samples have $\mathrm{K} / \mathrm{Rb}$ and $\mathrm{K} / \mathrm{Ba}$ values that fall dominantly within the range of values for Arikaree Group sands (Fig. 18a). On the other hand, dune sand samples have compositions that fall mostly outside the ranges of Pliocene sands, North Platte River sands, and South Platte River sands (Figs. 18b,c). Nebraska Sand Hills samples show fairly good compositional agreement with sands from Ogallala Group sediments (Fig. 18d). These results are in broad agreement with those of Muhs (2017), permitting an interpretation of Arikaree Group sands and/or Ogallala Group sands as dune sources.

Among the trace elements we employ here to explore potential sources for the Nebraska Sand Hills, plots of Sc, Th, and La are particularly effective in discriminating sediments of different origins (Taylor and McLennan, 1985; Bhatia and Crook, 1986; Olivarez et al., 1991). Scandium is enriched in pyroxenes from mafic igneous rocks, whereas Th and La have high concentrations in silicic rocks. Thus, on a ternary plot, sediments from mafic sources will plot near the Sc pole, whereas sediments from silicic sources will plot near the Th and La poles. Given that all the possible sources for the Nebraska Sand Hills are themselves derived mostly from rocks that have a dominantly upper continental crustal origin, we expected that samples would fall near the Th and La poles and this is found to be true (Fig. 19a). Nevertheless, within this broad range for average upper continental crustal rocks, there are small but important differences that are apparent. Nebraska Sand Hills samples fall only within the higher-La range of the field defined by Arikaree Group rocks (Fig. 19b). Generally lower relative La abundances for Pliocene sands, North Platte River sands, and South Platte River sands result in geochemical fields for Sc-Th-La that overlap very little with Nebraska Sand Hills sediments (Figs. 19c,d). However, as with the $\mathrm{K} / \mathrm{Rb}$ and $\mathrm{K} / \mathrm{Ba}$ fields, the Sc-Th-La data show good agreement between dune sands of the Nebraska Sand Hills and Ogallala Group sands (Fig. 19e).

As discussed in the methods section earlier, the REE are very sensitive indicators of sediments derived from rocks of different compositions. Loess is often considered to be a good example of sediment that is a natural composite of the upper continental crust and its REE composition reflects this (Taylor and McLennan, 1985; McLennan, 1989). Glacial till deposited by large, continental ice sheets, from which much loess is derived, also can be considered to be a natural, upper crust composite. This is particularly true in North America, where the Laurentide Ice Sheet eroded Precambrian igneous and metamorphic rocks, Paleozoic carbonate rocks, and Paleozoic and Mesozoic shales. Both loess and till from the Laurentide Ice Sheet in North America show REE abundance plots that are very similar to average upper continental crust. In Peoria Loess of western Iowa, Des Moines Lobe till of central Iowa, and James Lobe glacial till from southeastern South Dakota, REE plots show the salient features of average upper continental crustal compositions: (1) enrichment of light REE, (2) strongly negative Eu anomalies, and (3) a relatively "flat" curve for heavy REE (Figs. 20a,b). Aeolian sediments from the Nebraska Sand Hills show some similarities to average upper continental crust, with enriched light REE and somewhat depleted heavy REE, but importantly, most show only slightly negative Eu anomalies and two show positive Eu anomalies (Figs. 20c,d). 

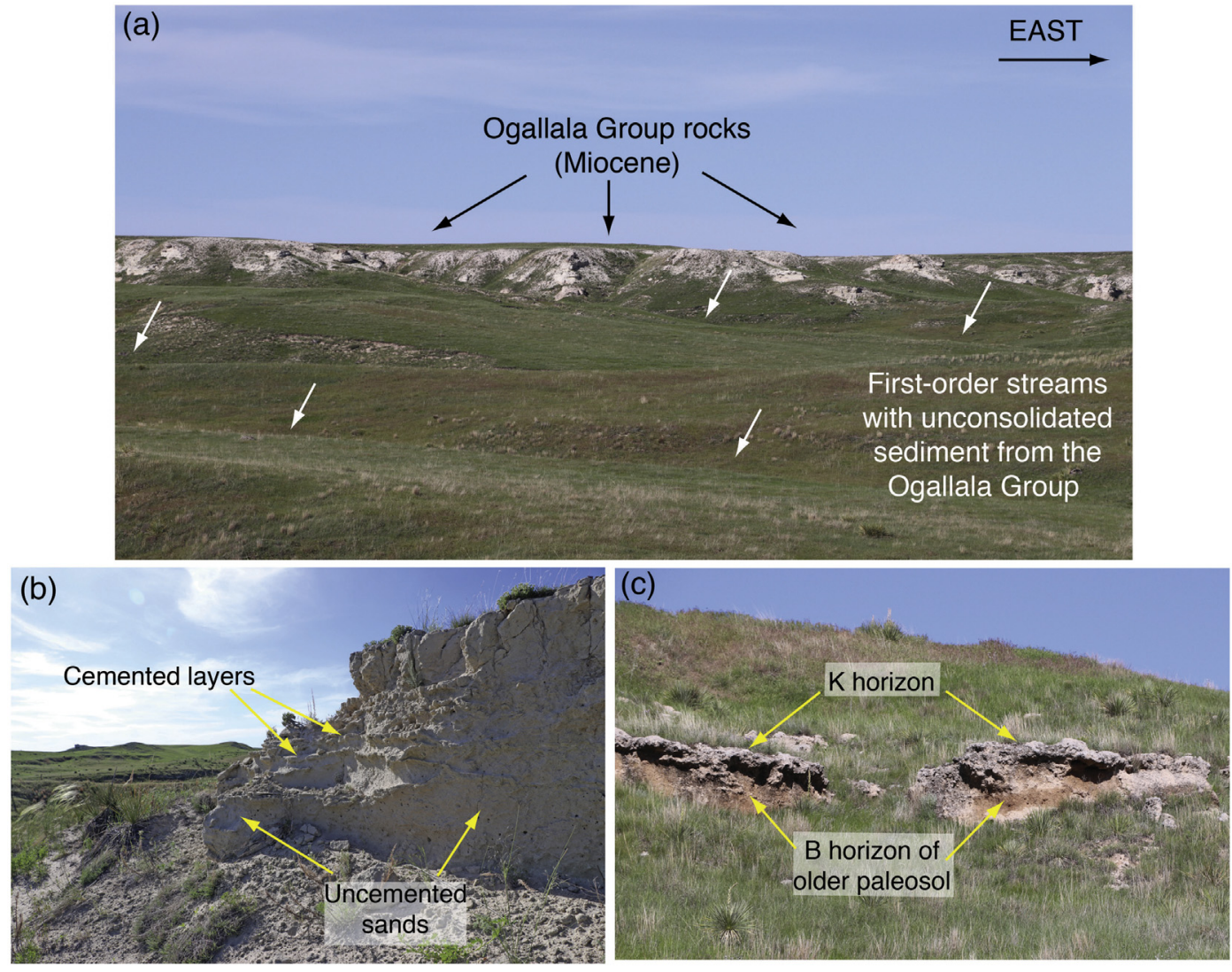

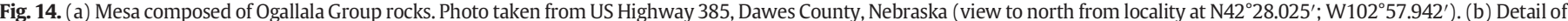

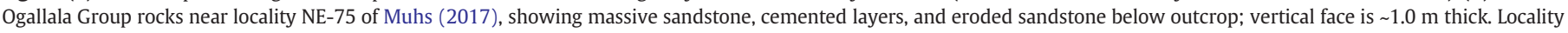

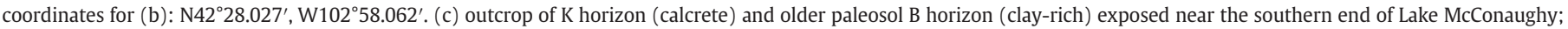
locality coordinates: N41 ${ }^{\circ} 12.149^{\prime}$, W101 ${ }^{\circ} 43.362^{\prime}$. Photos by D.R. Muhs.

Plots of $\mathrm{La}_{N} / \mathrm{Yb}_{\mathrm{N}}$ Vs. Eu/Eu* for potential source sediments of the $\mathrm{Ne}-$ braska Sand Hills show a surprisingly large range of values (Fig. 21). Samples from the Arikaree Group show a range of $\mathrm{La}_{N} / \mathrm{Yb}_{\mathrm{N}}$ values that are typical of upper crustal rocks, but have a broad range of $\mathrm{Eu} / \mathrm{Eu}^{*}$ values, from $\sim 0.4$ to $\sim 1.4$ (Fig. 21a). Pliocene sands have a much smaller range of values for both $\mathrm{La}_{\mathrm{N}} / \mathrm{Yb}_{\mathrm{N}}$ and $\mathrm{Eu} / \mathrm{Eu}^{*}$ (Fig. 21b). North Platte River sands define a $\mathrm{La}_{N} / \mathrm{Yb}_{\mathrm{N}} \mathrm{Vs}$. Eu/Eu* field that overlaps the Arikaree Group, but is smaller; South Platte River sands show lower $\mathrm{La}_{N} / \mathrm{Yb}_{\mathrm{N}}$ values (Fig. 21c). Sediments of the Ogallala Group define a $\mathrm{La}_{N} / \mathrm{Yb}_{\mathrm{N}} \mathrm{Vs}$. $\mathrm{Eu} / \mathrm{Eu}^{*}$ compositional field that has a similar range of $\mathrm{Eu} / \mathrm{Eu}^{*}$ values as Arikaree Group sediments, but with a much larger range of $\mathrm{La}_{N} / \mathrm{Yb}_{\mathrm{N}}$ values (Fig. 21d). Nebraska Sand Hills samples show a narrow range of $\mathrm{Eu} / \mathrm{Eu}^{*}$ values (though high compared to average upper crustal rocks), but a wide range of $\mathrm{La}_{N} / \mathrm{Yb}_{\mathrm{N}}$ values. Only those dune sands with the lowest $L a_{N} / Y b_{N}$ values overlap the fields for Arikaree Group rocks, Pliocene sands, and North Platte River sands, and there is no overlap of dune sands with South Platte River sands. In contrast, all but one of the dune sand samples overlap the compositional field for $\mathrm{La}_{N} / \mathrm{Yb}_{\mathrm{N}} \mathrm{Vs}$. $\mathrm{Eu} / \mathrm{Eu}^{*}$ defined by Ogallala Group sediments.

Although heavy minerals constitute a minority of the sediments of the Nebraska Sand Hills (Lewis, 1976; Winspear and Pye, 1996), such minerals have long been key provenance indicators in sedimentary petrology (Pettijohn et al., 1972). Here, we report two element ratios $(\mathrm{Fe} / \mathrm{Sc}$ and $\mathrm{As} / \mathrm{Sb}$ ) that are indicative of the composition of particles in the heavy mineral suite. A broad range of minerals host Fe, but one of the most important is pyroxene, which also hosts Sc. Magnetite is a major carrier of $\mathrm{As}$ and $\mathrm{Sb}$, and these elements can also be found in ilmenite and olivine (Onishi and Sandell, 1955; Esson et al., 1965). Arikaree Group sediments show a wide range of As/Sb values with a smaller range of Fe/Sc values (Fig. 22a). Pliocene sands show a much smaller range of both $\mathrm{As} / \mathrm{Sb}$ and $\mathrm{Fe} / \mathrm{Sc}$ values (Fig. 22b), but North Platte River sands, like Arikaree Group sands, show a broad range of $\mathrm{As} / \mathrm{Sb}$ values (Fig. 22c). South Platte River sands fall close to, but do not overlap North Platte River sands. Sediments of the Ogallala Group show a narrow range of $\mathrm{As} / \mathrm{Sb}$ values but a wide range of $\mathrm{Fe} / \mathrm{Sc}$ values (Fig. 22d). Nebraska Sand Hills sediments do not show the extreme ranges of As/ Sb values seen for Arikaree Group and North Platte River sands and overlap the fields of these source sediments only slightly (Arikaree Group) or not at all (North Platte and South Platte River sands). There is some overlap between dune sands and Pliocene sands, but the dune sands show a wider range of values for $\mathrm{Fe} / \mathrm{Sc}$. The dune sands show very good agreement with the range of both $\mathrm{As} / \mathrm{Sb}$ and $\mathrm{Fe} / \mathrm{Sc}$ seen in Ogallala Group sands.

\subsection{Relation of the Nebraska Sand Hills to loess in central and eastern Nebraska}

Loess is widespread over central and eastern Nebraska (Swinehart et al., 1994a; Mason, 2001; Muhs et al., 2008). It has long been hypothesized that the Nebraska Sand Hills are linked to the origin of loess in Nebraska and adjacent parts of Kansas (Lugn, 1939, 1962, 1968; Condra et al., 1947; Thornbury, 1965; Reed, 1968; Wright Jr., 1970). These early studies were not specific about the role that the Nebraska Sand Hills might have played in loess genesis, although most investigators seem to have perceived loess to be a downwind, finer-grained facies of the dune sand, with both having a common source or sources. Here we present additional geochemical data to evaluate this hypothesis.

To compare the composition of loess in central and eastern Nebraska with that of dune sand from the Nebraska Sand Hills, we analyzed lastglacial-aged (Peoria) loess from two loess sections (near Elba and 

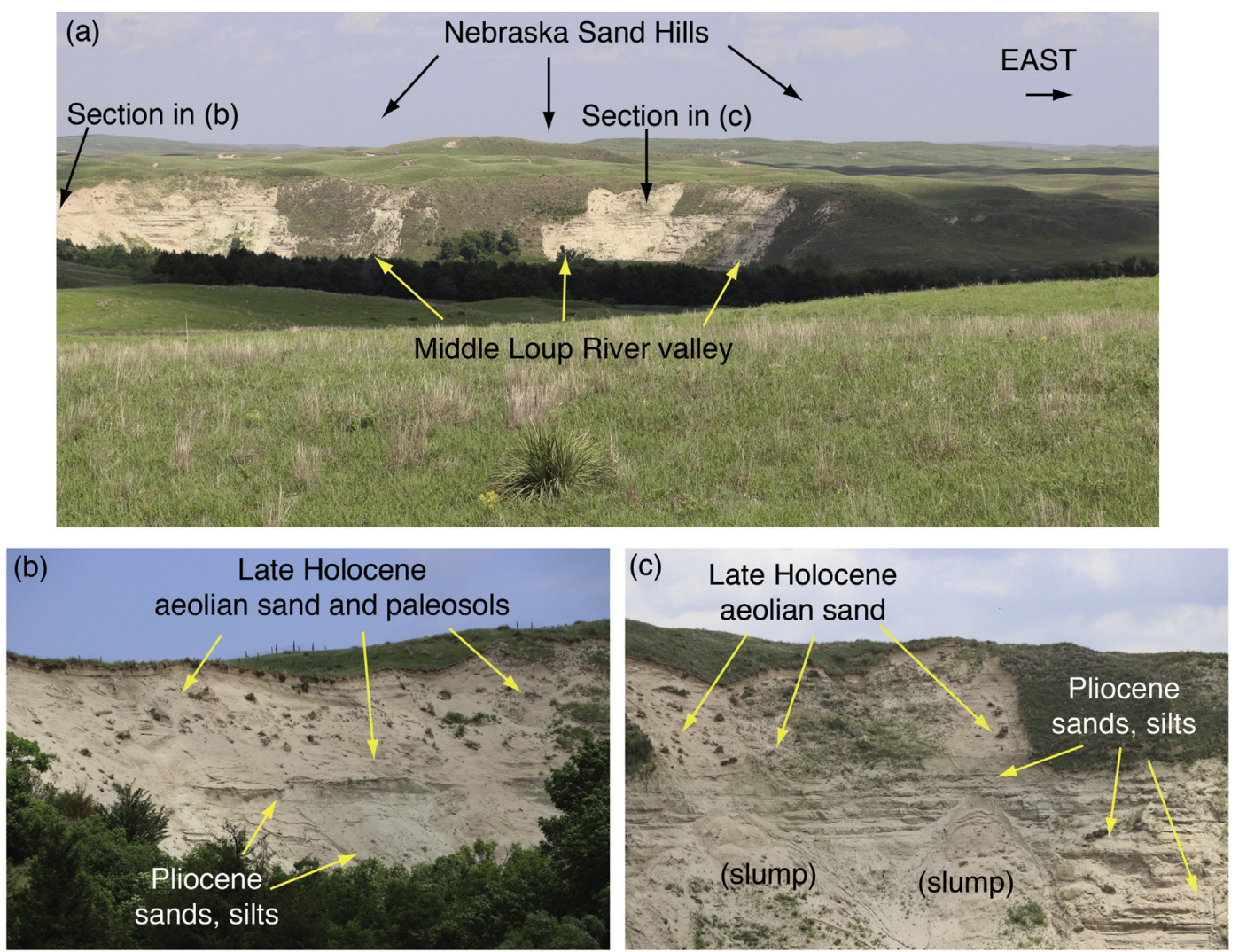

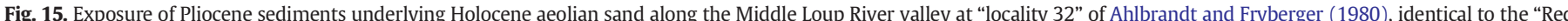

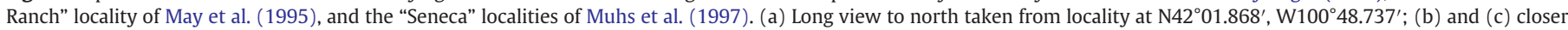

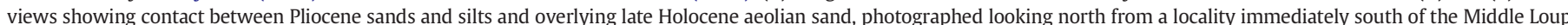

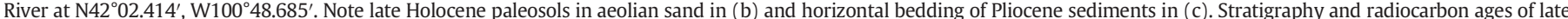
Holocene aeolian sand can be found in Muhs et al. (1997). Photographs by D.R. Muhs.

Lincoln, Nebraska) previously studied by Muhs et al. (2008). Four samples from each section, at depths of $150 \mathrm{~cm}$ to $350 \mathrm{~cm}$, were analyzed. Results show that Nebraska loess and dune sand define distinct geochemical fields on a K/Ba vs. K/Rb plot, indicating that K-feldspar and/or mica populations were derived from different source rocks (Fig. 23a). On a Sc-Th-La plot, both sediment groups plot, at least

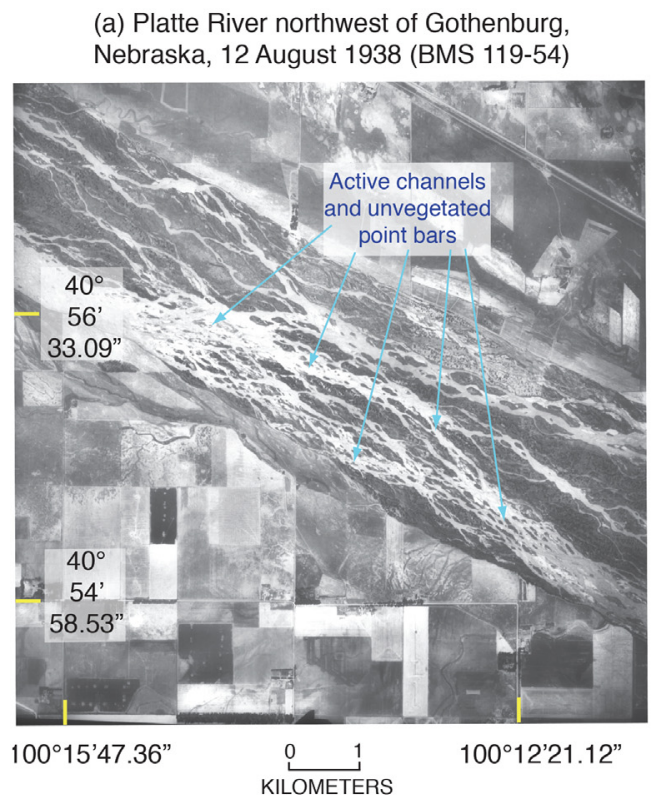

(b) Platte River northwest of Gothenburg, Nebraska, 11 April 1999 (USGS NAPP 11273-202)

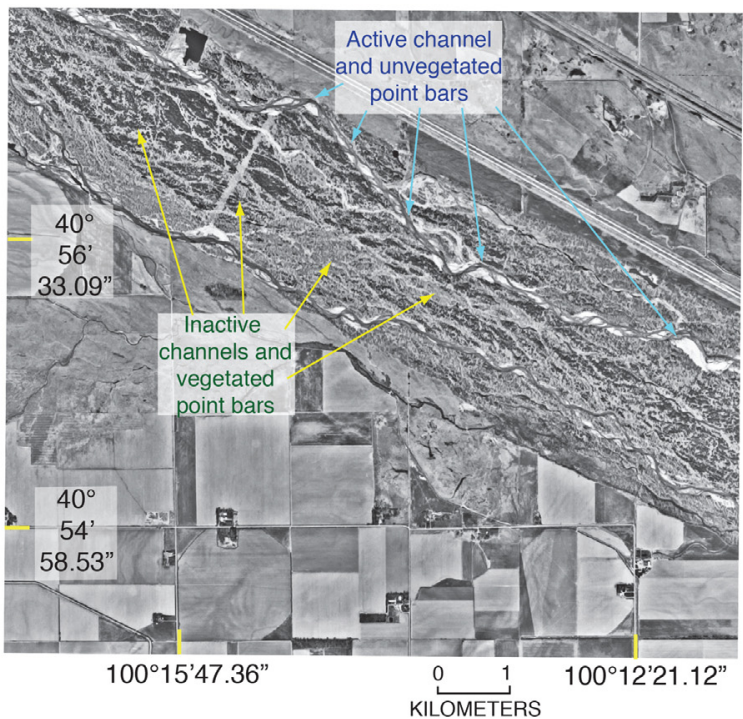

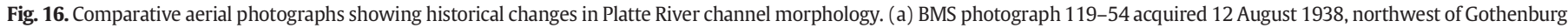

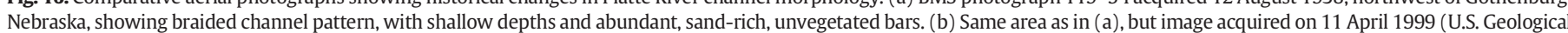
Survey NAPP 11273-202 photograph), showing single main channel and largely vegetated floodplain, former channels, and bars. 
(a)

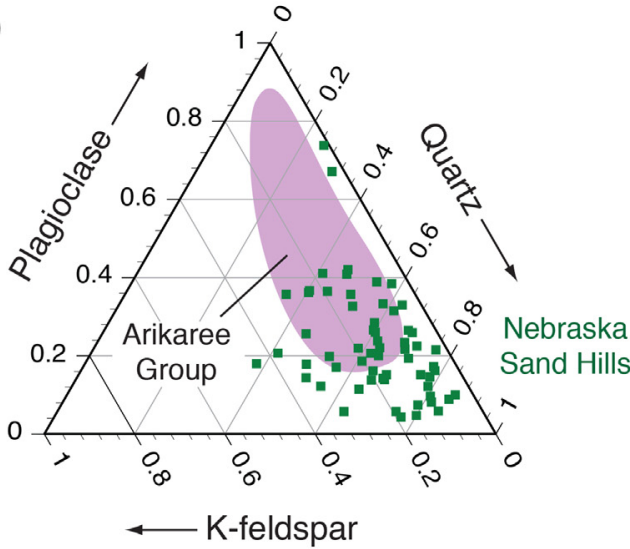

(c)

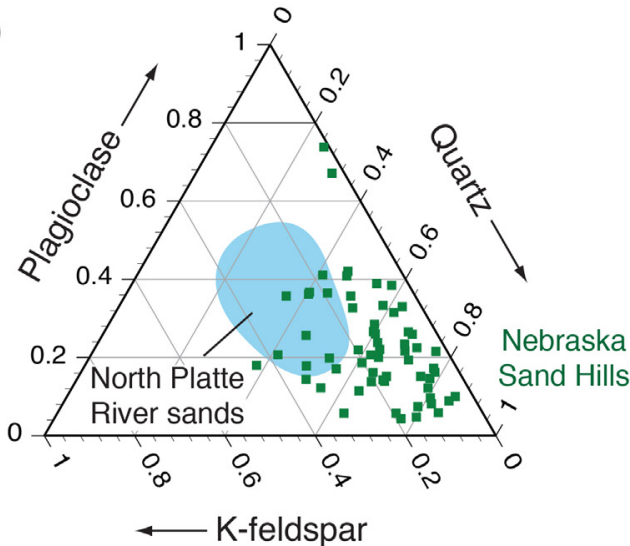

(b)

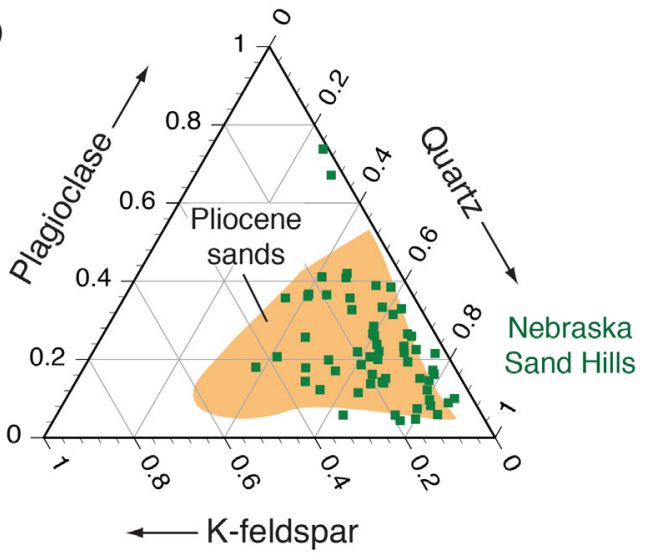

(d)

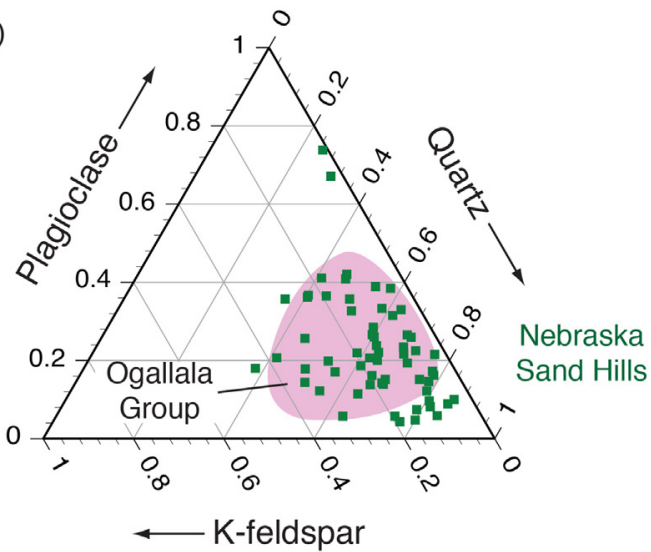

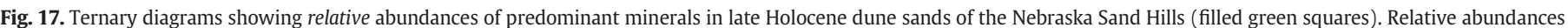

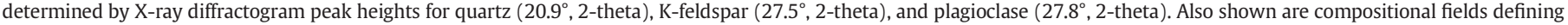

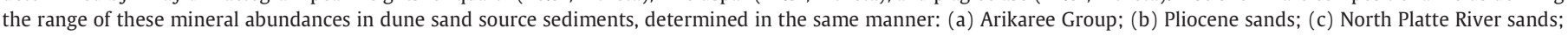
(d) Ogallala Group sands.

broadly, within the range of average upper continental crust, but loess and dune sand define distinct geochemical fields (Fig. 23b). Similar to loess deposits from many regions (see examples in Muhs, 2018), Nebraska loess samples have REE compositions that fall close to that of average upper continental crust. However, Nebraska loess samples have both lower $\mathrm{La}_{\mathrm{N}} / \mathrm{Yb}_{\mathrm{N}}$ and $\mathrm{Eu} / \mathrm{Eu}^{*}$ values compared to dune sediments of the Nebraska Sand Hills (Fig. 23c). Finally, measures of trace element compositions in the heavy mineral fraction, using $\mathrm{Fe} / \mathrm{Sc}$ and $\mathrm{As} / \mathrm{Sb}$, show no overlap between loess and dune sand in Nebraska (Fig. 23d).

\section{Discussion}

\subsection{Source of sediment in the Nebraska Sand Hills: previous hypotheses}

Early investigators of the Nebraska Sand Hills did not have access to the tools available today for provenance studies, but they offered hypotheses about the source of sand of this large dune field. Lugn (1939, $1962,1968)$ considered that both the Ogallala Group and sediments reworked from it were the sources of both the Nebraska Sand Hills and loess to the southeast of the dune field. Thornbury (1965) articulated the same concept as Lugn for the origin of the Nebraska Sand Hills. In addition, however, Thornbury (1965) stated that the upper part of the Ogallala Group is missing beneath the Sand Hills and the overall elevation of the dune field is lower than that of the High Plains region to the west. This suggested to him that major erosion occurred before the dune field formed. It is important to note, however, that Thornbury (1965) provided no subsurface data to support these claims. In fact, it is not certain that such data even existed at the time he made these statements. Smith (1965) rejected the concept that the Nebraska Sand Hills owed their origins to the Ogallala Group, considering Lugn's (1962) explanation to be oversimplified. Further, Smith (1965) pointed out that the Ogallala Group is indurated in many places and is therefore unlikely to have been a very important source for dune sand. Based on more recent studies, however, it is actually Smith's (1965) statement about induration in the Ogallala Group that is oversimplified. Joeckel et al. (2014) conducted detailed sedimentological studies of the Ash Hollow Formation of the Ogallala Group. These investigators pointed out that very fine to fine-grained sandstone is the predominant facies in this formation and that the sediments are well sorted and only weakly cemented. The observations of Joeckel et al. (2014) are consistent with those made in the present study. To be fair, Smith (1965) did speculate, however, that reworked Ogallala Group sediments could be a more likely source for the Nebraska Sand Hills, in agreement with Lugn $(1939,1962,1968)$. Smith (1965) also hypothesized that Pleistocene sediments in Nebraska, including the Nebraska Sand Hills, could have had sources farther west. Precisely what "western" sources Smith (1965) was referring to is not clear, nor did he present evidence for this hypothesis. Reed (1968) also considered that unconsolidated Pleistocene sediments, reworked from the Ogallala Group, were a likely source for the Sand Hills. Extending this argument further, Wright Jr. (1970) pointed out that with time, an eroding Ogallala Group surface might have been buried by aeolian sand, and subsequent dune field growth would have to come from sources farther to the northwest, such as the Tertiary White River Group (Fig. 5). Wright Jr. et al. (1985) reiterated the concept of a White River Group source in a later study. Although this idea is intriguing, it is problematic in that the White River 

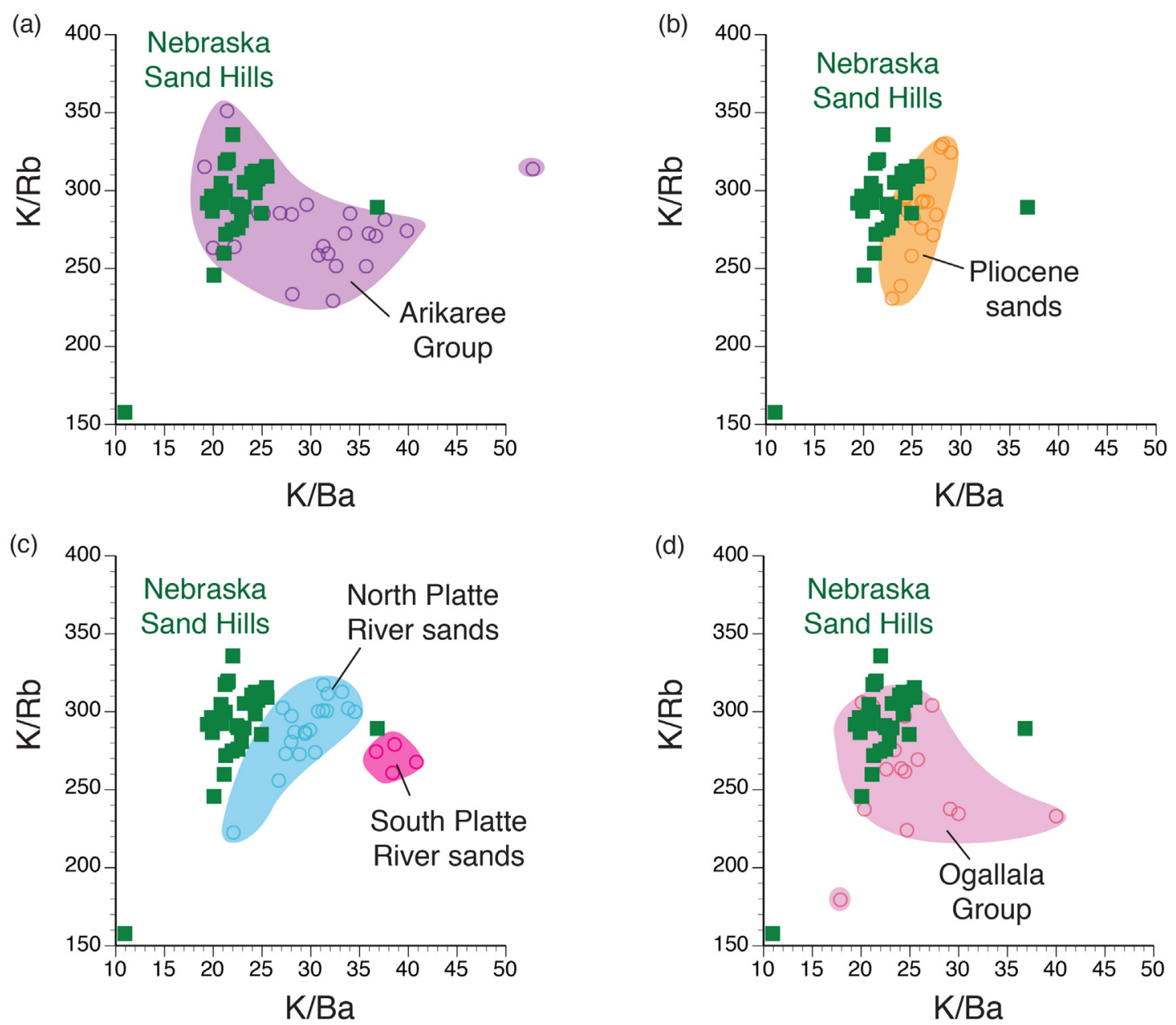

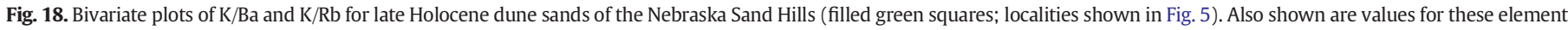

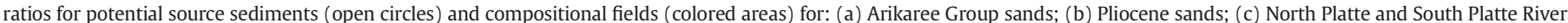

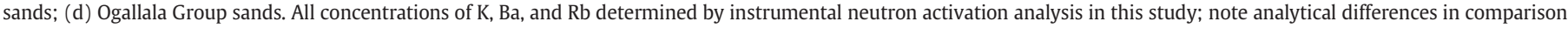
with Fig. 29 of Muhs (2017), where same sample groups were analyzed for K, Ba, and Rb by energy-dispersive X-ray fluorescence (see text for discussion).

Group is dominated by silt, not sand. Aleinikoff et al. (2008) showed that K-feldspars in the White River Group have Pb-isotopic compositions that differ from those of the Nebraska Sand Hills.

Later investigators proposed younger sediments as sources of the Nebraska Sand Hills. Warren (1976) considered, on the basis of particle-size data, that underlying fluvial sands were the source of the dunes, but was not specific as to where these sediments came from. Swinehart (1990) also proposed that fluvial sands of Quaternary and Pliocene age, beneath the Sand Hills, were the primary sources of sand, along with some contributions from the Ogallala Group. Pliocene sediments were also favored by May et al. (1995) as a likely source for the Nebraska Sand Hills. Winspear and Pye (1996) analyzed fluvial sands from beneath the dunes and aeolian sands from the Nebraska Sand Hills for both mineralogy and geochemistry. Their data suggest little difference in composition between the two except that K-feldspar is less abundant in the Nebraska Sand Hills than in the underlying fluvial sands.

As mentioned already, Muhs (2017) evaluated the same four potential source sediments considered in the present study. On the basis of K/ $\mathrm{Rb}$ and $\mathrm{K} / \mathrm{Ba}$, Muhs (2017) concluded that sediments of the Ogallala Group and/or sediments derived from it are the most likely sources for the Nebraska Sand Hills, a return to earlier hypotheses. Nevertheless, contributions from sources other than the Ogallala Group were recognized as possibilities, requiring further study.

\subsection{Source of sediment in the Nebraska Sand Hills: geochemistry}

A first consideration in evaluating source sediments is mineralogy. Although a potential source of aeolian sand may contain a broader suite of minerals than what is found in the dune field downwind, it obviously must at least contain all of the minerals found in that dune field. Mineralogical data indicate that sediments of all potential sources considered, including the Arikaree Group, Ogallala Group, Pliocene sands, and North Platte River sands, contain the requisite species within the light mineral fraction, which constitutes the majority of particles. Sediments of the Nebraska Sand Hills are dominated by quartz, K-feldspar, and plagioclase. Although the dune sands are more quartz-rich than most of the possible source sediments, all potential sources contain quartz, K-feldspar, and plagioclase (Fig. 17).

Geochemical results support some of the hypotheses of earlier investigators and eliminate others. In a re-evaluation of the $\mathrm{K} / \mathrm{Rb} \mathrm{vs}$. $\mathrm{K} / \mathrm{Ba}$ composition (primarily as a proxy for K-feldspar) of source sediments investigated by Muhs (2017), new results presented here show similar ranges of values compared to the earlier study, although offset to lower values, as discussed earlier (Fig. 18). Samples from the Nebraska Sand Hills have minimal overlap with Pliocene sands and almost no overlap with the range of $\mathrm{K} / \mathrm{Rb}$ and $\mathrm{K} / \mathrm{Ba}$ values for North Platte River and South Platte River sands. In contrast, samples from the Nebraska Sand Hills show considerable overlap with the ranges of $\mathrm{K} / \mathrm{Rb}$ and $\mathrm{K} / \mathrm{Ba}$ values 


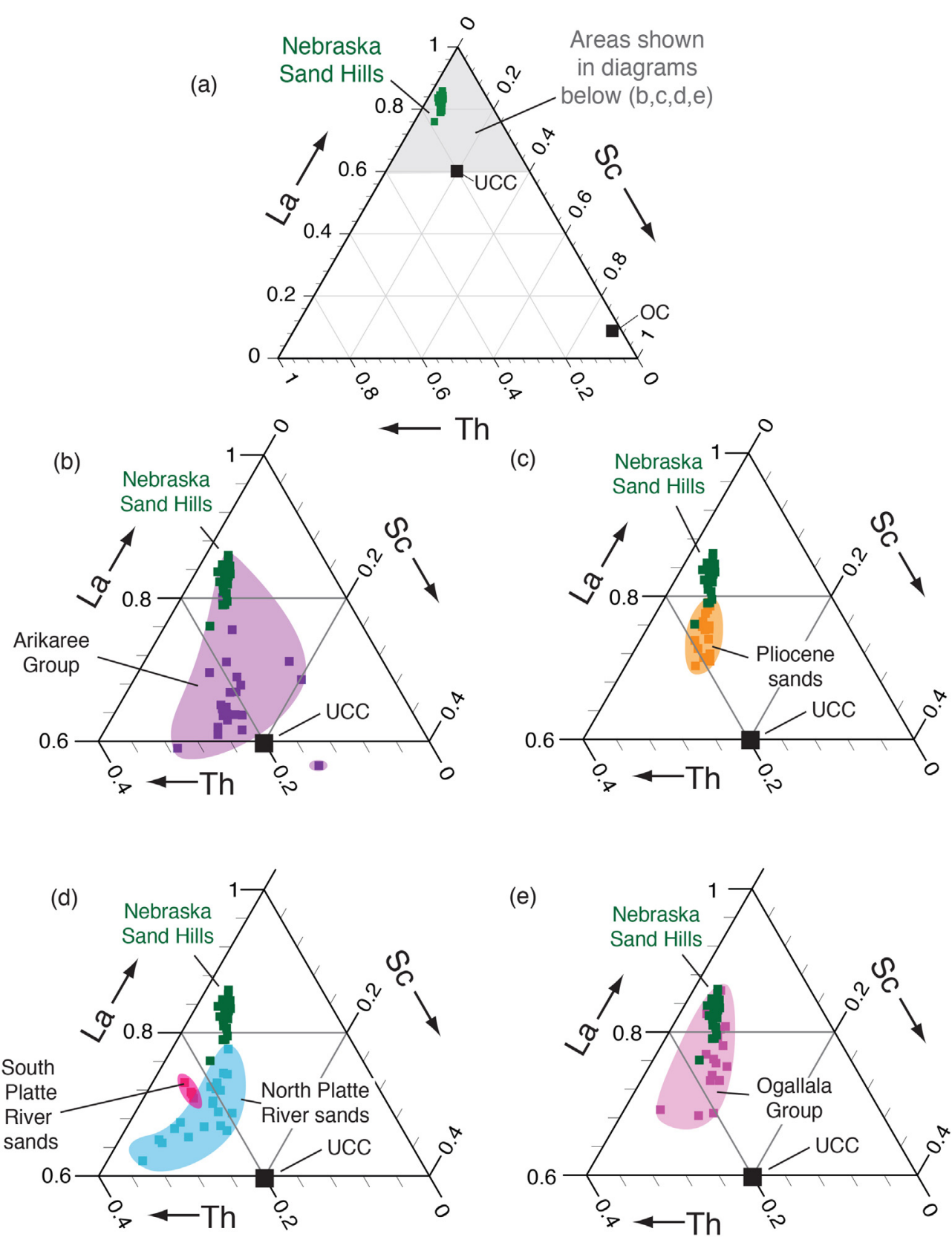

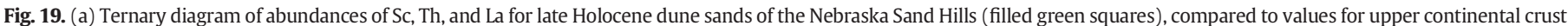

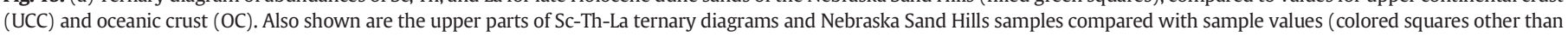

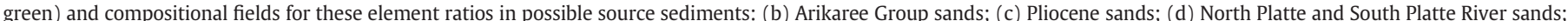
(e) Ogallala Group sands. Concentrations of all elements determined by instrumental neutron activation analysis in this study. UCC and OC values from Taylor and McLennan (1985).

for both Arikaree Group and Ogallala Group sands. Thus, either or both of these source sediments could have been important contributors to the Nebraska Sand Hills.

A similar interpretation can be made on the basis of the Sc-Th-La compositions of the various source sediments compared to the samples from the Nebraska Sand Hills. Ternary plots of Sc-Th-La indicate that all of the candidate source sediments plot near the value for average upper continental crustal rocks (Fig. 19). This result is not surprising, as mafic rocks have contributed only minor amounts of material to the source sediments considered here (Stanley, 1976; Swinehart et al., 1985). Pliocene sands show the smallest range in variability and the Arikaree Group shows the greatest range of variability. Sediments of the Nebraska Sand Hills show only slight overlap with the range of Pliocene sands and no overlap with North Platte River or South Platte River sands. However, all samples from the Nebraska Sand Hills fall within the range of values for the Arikaree Group and Ogallala Group sands, permitting an interpretation of either or both of these sediments as sources.

The REE compositions of possible source sediments show considerable variability. The Arikaree Group shows a wide range in $\mathrm{Eu} / \mathrm{Eu}^{*}$ values and the Ogallala Group shows a wide range in $\mathrm{La}_{N} / \mathrm{Yb}_{\mathrm{N}}$ values (Fig. 21). The relatively high $\mathrm{Eu} / \mathrm{Eu}^{*}$ values in some of the Arikaree Group and Ogallala Group samples could be due to a component of feldspar inputs from the anorthosites of the southern Laramie Mountains (Fig. 2). Anorthosites in these mountains have positive Eu anomalies (Frost et al., 2010). In contrast, other source rocks in southeastern Wyoming and northeastern Colorado, such as granite in the Sherman batholith (Fig. 2), have negative Eu anomalies (Frost et al., 1999). On 
(a) Peoria loess, Sioux City, western lowa

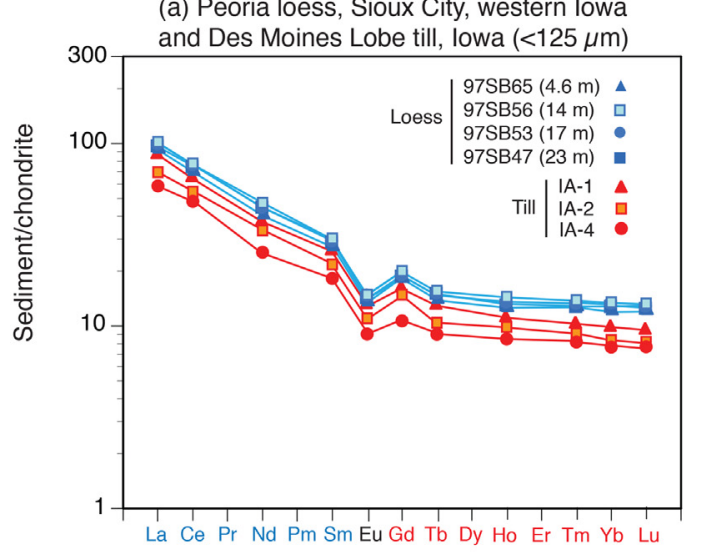

(b) James Lobe till, South Dakota $(<125 \mu \mathrm{m})$

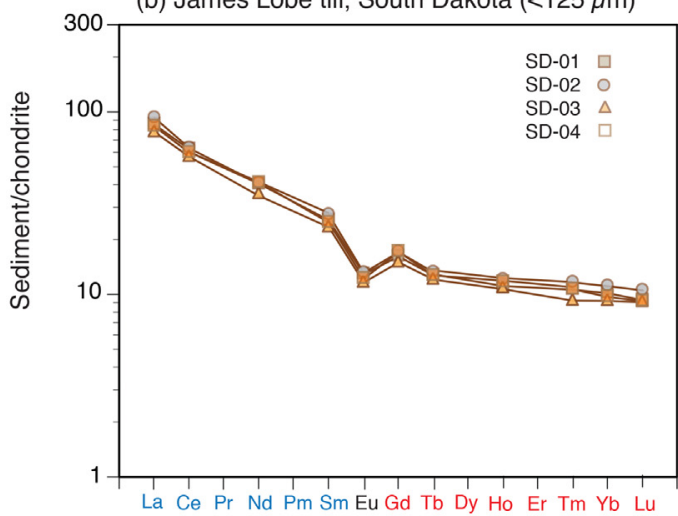

(c) Nebraska Sand Hills

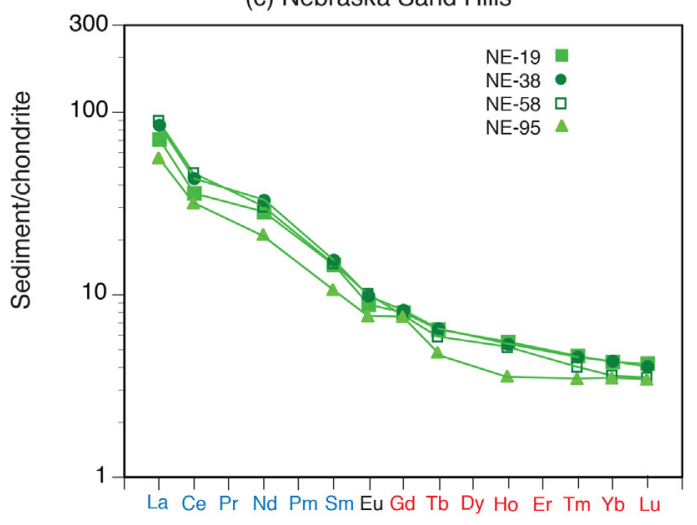

(d) Nebraska Sand Hills

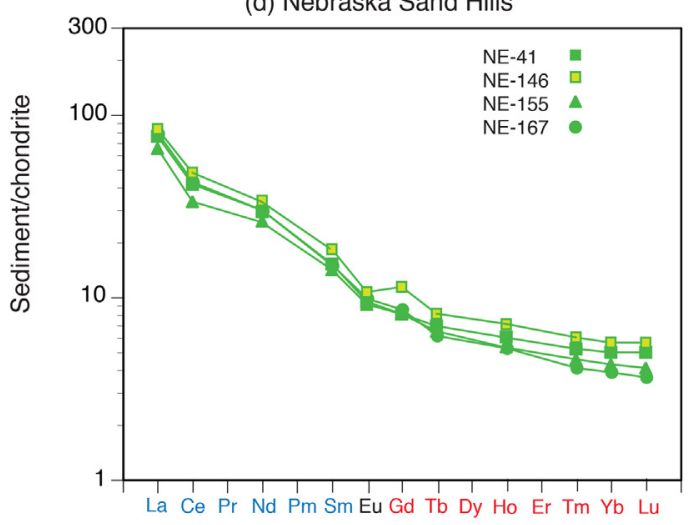

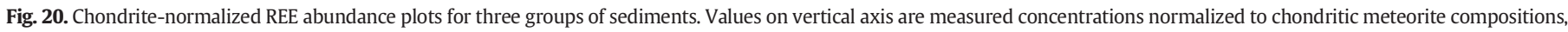

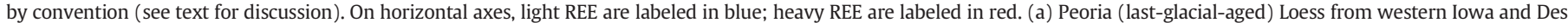

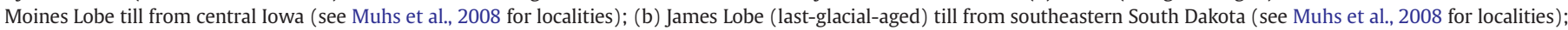

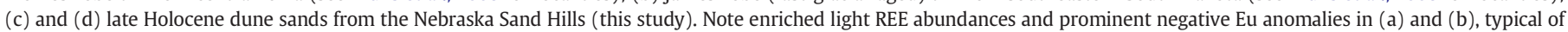

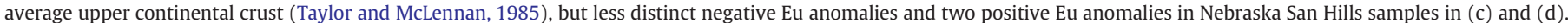
Concentrations of all elements determined by instrumental neutron activation analysis from this study.

$\mathrm{La}_{\mathrm{N}} / \mathrm{Yb}_{\mathrm{N}}$ Vs. Eu/Eu* plots, Nebraska Sand Hills samples show modest overlap with the ranges of values for Arikaree Group, Pliocene, and North Platte River sediments. However, Nebraska Sand Hills sediments show excellent agreement with the range of values for both $\mathrm{La}_{N} / \mathrm{Yb}_{\mathrm{N}}$ and $\mathrm{Eu} / \mathrm{Eu}^{*}$ observed in sands from the Ogallala Group.

Finally, element ratios representing the heavy mineral fraction, $\mathrm{Fe} / \mathrm{Sc}$ vs. As/Sb, provide additional support for an Ogallala Group source for the Nebraska Sand Hills (Fig. 22). While the Arikaree Group and Pliocene sands show some overlap with the composition of the Nebraska Sand Hills, North Platte River and South Platte River sands show no overlap. However, the range of $\mathrm{Fe} / \mathrm{Sc}$ and $\mathrm{As} / \mathrm{Sb}$ compositions of samples from the Nebraska Sand Hills show excellent agreement with the range of values for sands of the Ogallala Group.

\subsection{Source of sediment in the Nebraska Sand Hills: geomorphic considerations}

Based on geomorphic and climatic considerations, sand of the North Platte, South Platte, and Platte Rivers would seem to be very likely sources for the Nebraska Sand Hills. These rivers are situated to the west, southwest, south, and southeast of the dune field (Figs. 3-5) and are therefore at present upwind of the sand sea in late spring and summer, when sediments are not frozen or snow-covered (Fig. 4b). Unlike the sediments of the Arikaree and Ogallala Groups, modern sediments of these rivers are uncemented. Furthermore, prior to regulation, the Platte River system, with a broad, sandy, vegetation-free bar-andchannel system may have been an ideal geomorphic setting for aeolian sand input to the Nebraska Sand Hills. Nevertheless, the geochemical data do not indicate that sediments from the Platte River system were important sources for the Nebraska Sand Hills.

Sridhar et al. (2006) and Schmeisser et al. (2010) proposed that during the Medieval Warm Period ( 1000 to $~ 800$ yr B.P.) of the late Holocene, there was a seasonal shift in wind regime over the Nebraska Sand Hills, with northwesterly winds dominant during fall, winter and early spring, but southwesterly winds (associated with very warm, dry air masses, and bringing drought) in late spring and summer. This seasonal shift in wind regime is invoked to explain the northwest-to-southeast orientation of linear dunes with bimodal dip directions, found in the southeastern part of the Nebraska Sand Hills. With this sort of shift in wind regime, these would seem to be ideal conditions for transport of sand from the North Platte River or Platte River to the Nebraska Sand Hills. While we do not dispute this scenario, the geochemical data presented here imply that sand inputs during such a wind regime must have been minimal. It is certainly possible, however, that this shift in wind regime during the Medieval Warm Period reworked pre-existing sand into linear dunes, but with little or no new sand input.

The best overall agreement of the geochemistry of the Nebraska Sand Hills is with sediments of the Ogallala Group. The Ogallala Group crops out extensively to the northwest of the Nebraska Sand Hills in western Nebraska (Figs. 5 and 24), as well as in southern South Dakota and eastern Wyoming, which is consistent with the paleowind reconstructions of the dune field, both for the youngest (Holocene) dunes (Fig. 3) and also the much larger and older barchanoid ridges and barchans (Figs. 6-8). It is also possible that widespread, late Tertiary or 

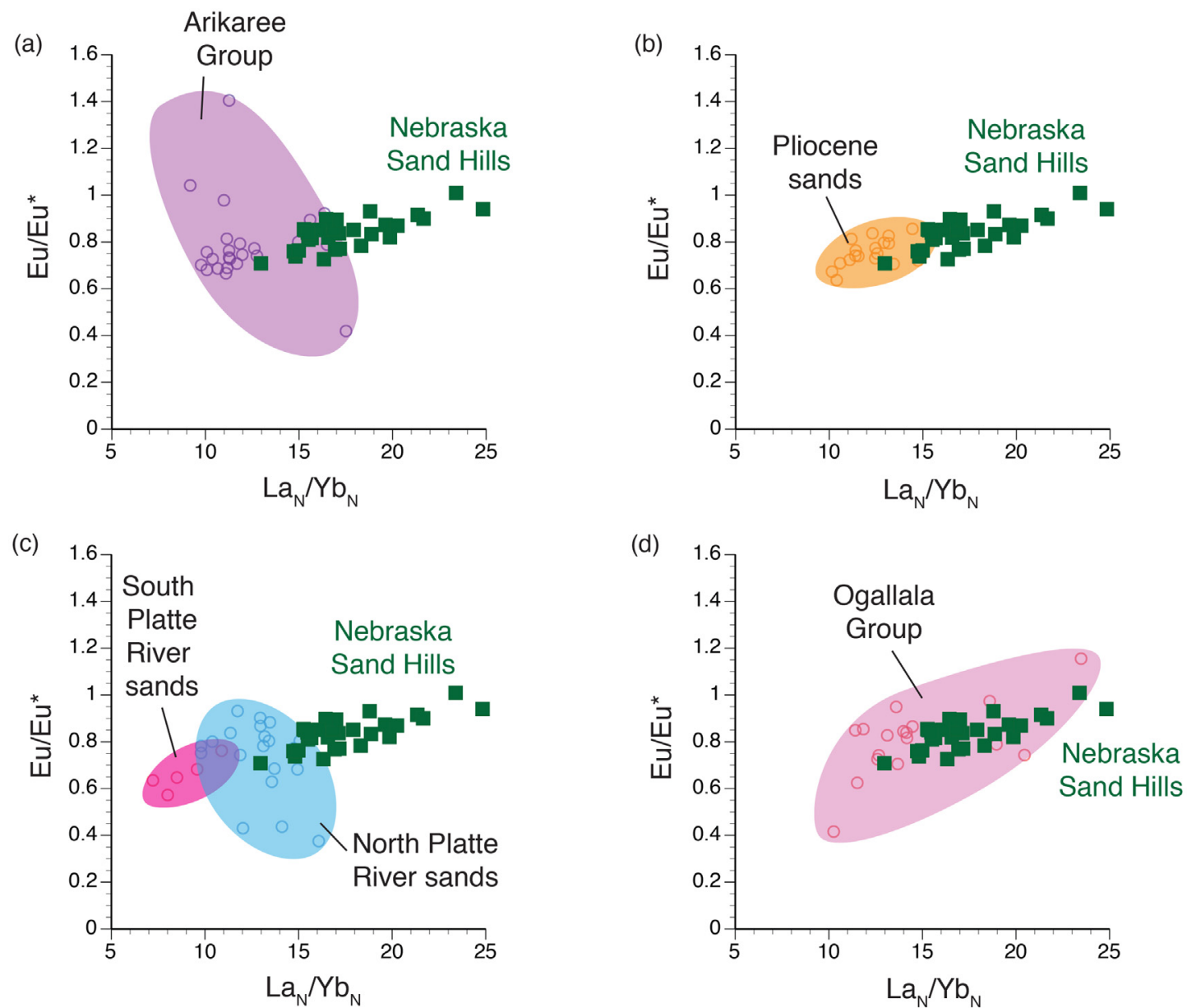

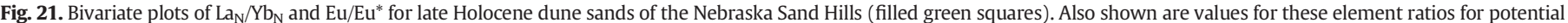

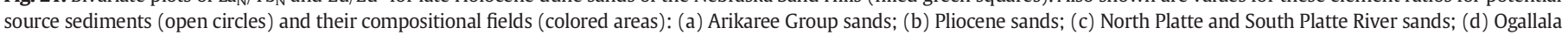
Group sands. Concentrations of all elements determined by instrumental neutron activation analysis from this study.

early Quaternary stripping of the Ogallala Group, found beneath the present location of the dune field (Swinehart and Diffendal, 1990), could have provided much of the initial sediment that forms the present Nebraska Sand Hills.

Even without such a Tertiary and/or early Quaternary period of erosion, examination of the present geomorphology of western Nebraska permits an interpretation of how Ogallala Group sediments might be delivered to the Nebraska Sand Hills. The surface of the Great Plains is often perceived as a flat, featureless plain. Even relatively recent texts describe it as a "...little dissected, gently east-tilted, flat, plateau surface, underlain, in most areas, by the hard caliche caprock layer that forms the top of the Ogallala formation..." (DiPietro, 2013, p. 125). Indeed, with a widespread calcrete caprock aiding in its preservation as broad mesas, Smith (1965), as noted above, did not consider the Ogallala Group to be a particularly important source for dunes of the Nebraska Sand Hills. When examined at a more detailed scale, however, the landscape of western Nebraska is not really a featureless plain. We mapped the drainages of western Nebraska from USGS 1:250,000-scale topographic maps. While consideration of drainages at this scale may not even include many first-order or even second-order streams, it provides documentation of at least the minimum amount of dissection that has taken place in this region. We superimposed these drainages on the bedrock geology of the region, derived from Swinehart et al. (1985). Although all rock units exhibit stream dissection at this scale, by far the greatest drainage density overall is on the landscapes where the Ogallala Group crops out at the surface (Fig. 24a). Tributaries to the Niobrara River, North Platte River, and Lodgepole Creek have dissected much of the total area where the Ogallala Group is exposed at the surface (Figs. 24b,c; see also Fig. 14). The importance of this is that, contrary to Smith's (1965) proposal, there is a significant amount of area to the northwest and southwest of the Nebraska Sand Hills, where unconsolidated sediments derived from the Ogallala Group could be subject to entrainment by wind during dry periods. Thus, while we agree that little erosion is likely to have taken place from those areas where the calcrete caprock forms a protective cover for the Ogallala Group, there is also a considerable amount of area where this caprock is missing. These parts of the landscape could supply sediment to the Nebraska Sand Hills during any period when the climate was dry enough that a protective vegetation cover was lacking.

\subsection{Relation of the Nebraska Sand Hills to loess in central and eastern Nebraska}

A recurring question that has occurred in studies of the Nebraska Sand Hills is the relation of this aeolian sand to loess that is found to the east, southeast, and south of the dune field (Lugn, 1939, 1962, 1968; Condra et al., 1947; Smith, 1965; Thornbury, 1965; Reed, 1968; Wright Jr., 1970; Ahlbrandt and Fryberger, 1980). As mentioned earlier, many of the early studies seem to have considered loess to be a downwind, finer-grained facies of the dune sand. An interpretation of a facies relationship between dune sand and loess implies a common source or sources for both sediment groups. This concept is suggested even in recent summaries of the origin of the Nebraska Sand Hills and adjacent loess regions (e.g., DiPietro, 2013, p. 99). Lugn $(1939,1962,1968)$ was 
(a)

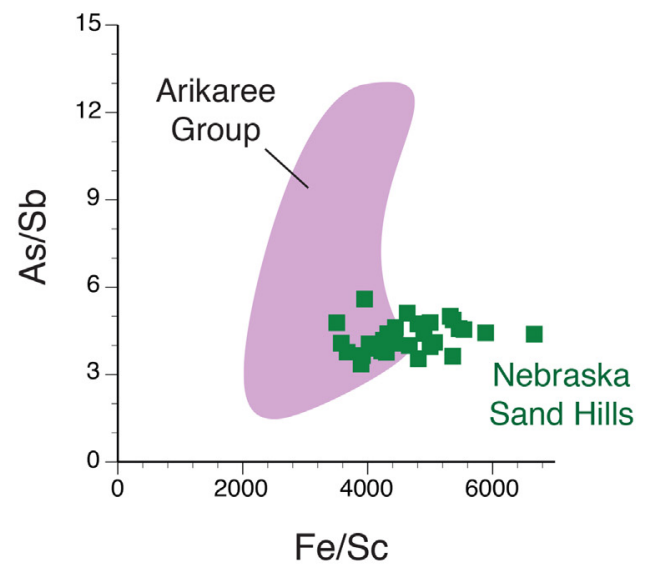

(c)

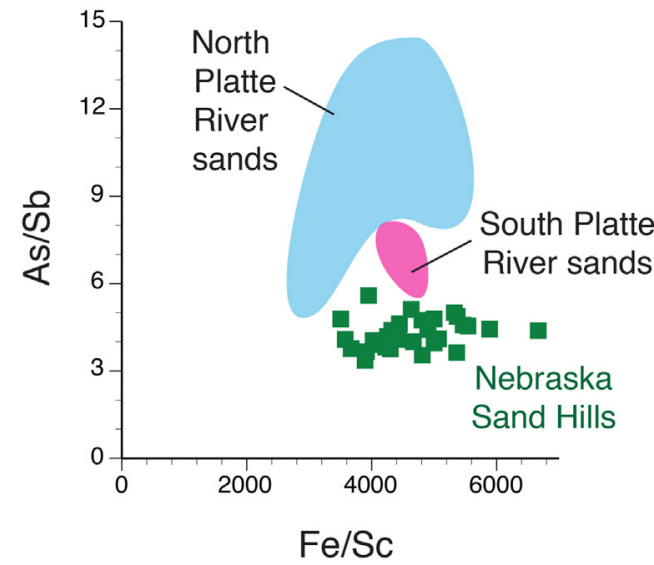

(b)

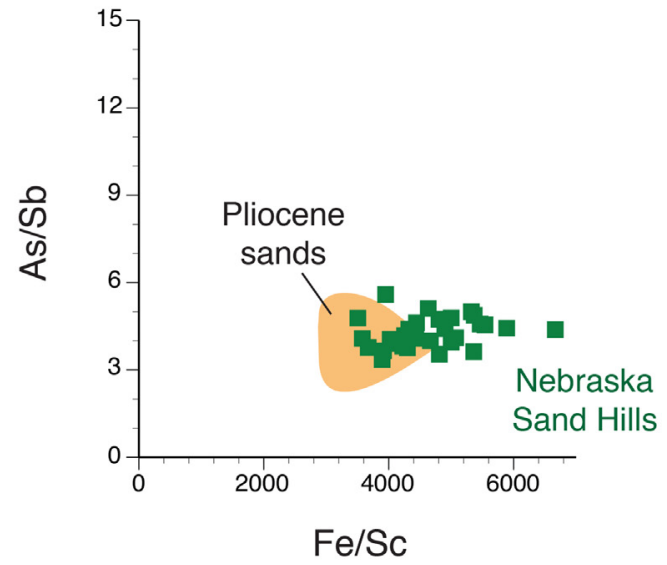

(d)

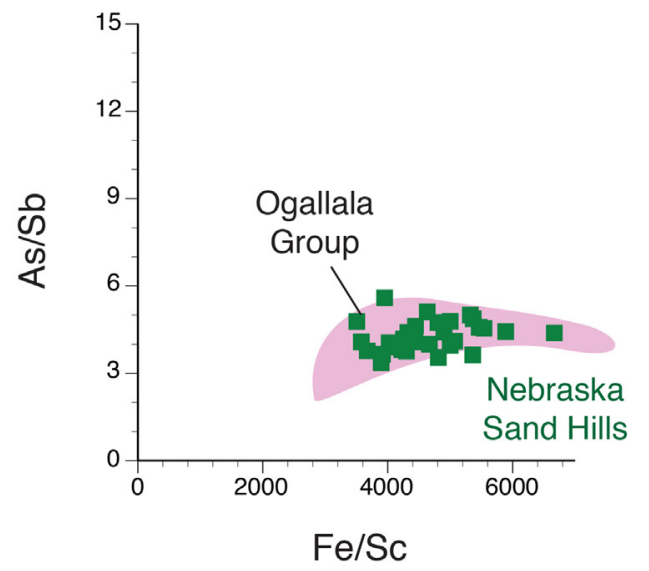

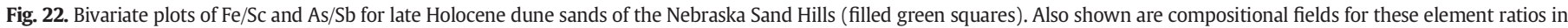

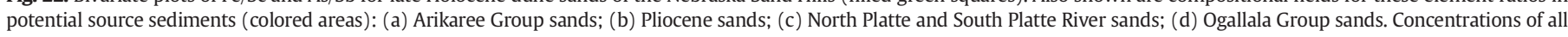
elements determined by instrumental neutron activation analysis from this study.

actually fairly specific about this, and indicated that the Ogallala Group was the ultimate source for both dune sand and loess in Nebraska.

Interestingly, it is now known that the timing of dune formation and loess accumulation in Nebraska is similar. Miao et al. (2007) showed that dune formation in the Holocene matches the timing of accumulation of Bignell Loess to the southeast of the Nebraska Sand Hills. In addition, the largest dunes of the Nebraska Sand Hills, the barchanoid ridges and barchans, were active during the last glacial period (Mason et al., 2011), similar to the timing of loess accumulation southeast of the $\mathrm{Ne}-$ braska Sand Hills (Roberts et al., 2003; Muhs et al., 2008). A similar timing of both dune activity and loess accumulation during both the late Pleistocene and Holocene does not, of course, require identical sediment sources. It means only that environmental controls on aeolian particle entrainment, transport, and accumulation (sediment supply, climate, vegetation cover) were likely similar for both sand and loess. With regard to Peoria Loess of last-glacial age in Nebraska, Aleinikoff et al. (2008) and Muhs et al. (2008) reported isotopic $\left({ }^{206} \mathrm{~Pb} /{ }^{204} \mathrm{~Pb}\right.$ and ${ }^{207} \mathrm{~Pb} /{ }^{204} \mathrm{~Pb}$ ) and geochemical (K/Rb values) evidence to show that dune sands of the Nebraska Sand Hills and loess of central and eastern Nebraska had different sources. The most important source of silt in Peoria Loess of Nebraska is volcaniclastic siltstone of the White River Group.

The trace element geochemical data presented here are consistent with the conclusions of Aleinikoff et al. (2008) and Muhs et al. (2008) that sediments of the Nebraska Sand Hills and Peoria Loess of Nebraska had different sources. Values of K/Rb and K/Ba, Sc-Th$\mathrm{La}, \mathrm{Eu} / \mathrm{Eu}^{*}, \mathrm{La}_{\mathrm{N}} / \mathrm{Yb}_{\mathrm{N}}, \mathrm{As} / \mathrm{Sb}$, and $\mathrm{Fe} / \mathrm{Sc}$ all show that the compositions of dune sediments of the Nebraska Sand Hills and Peoria Loess of Nebraska are distinctive (Fig. 23). Peoria Loess of Nebraska has a composition that is close to average upper continental crust, similar to loess found in many other regions of the world. If our interpretation of the Ogallala Group as the main source for the Nebraska Sand Hills is correct, then it is expected that dune sand, derived from this source, and loess, derived from the White River Group, should be compositionally distinct. Detailed petrographic studies by Stanley (1976) indicate that sediments of the Ogallala Group in eastern Wyoming and western Nebraska were derived not only from sources such as the Laramie Range, but also sources west of the Front Range, such as volcanic rocks in the North Park basin of Colorado (see Tweto, 1979). In contrast, the fine-grained volcaniclastic silts of the White River Group are derived from more distal sources (Swinehart et al., 1985), including volcanic centers in southern Colorado and possibly volcanic centers farther west, in the Basin and Range Province (Fig. 1). From all of these considerations, along with the geochemical data reported here, we conclude that the sediments of the Nebraska Sand Hills and Peoria Loess of central and eastern Nebraska had separate sources, though both areas may have been experiencing active sediment transport at the same time. Mason (2001) and Muhs et al. (2008) presented a model showing that silt-sized particles, derived from the White River Group, may have been transported through the Nebraska Sand Hills, while the dunes were active, and these particles accumulated as loess farther downwind. In this scenario, however, the dune field contributes little or nothing to the loess itself, but serves merely as a sediment transport pathway. This kind of process is referred to as "sediment bypassing” by Kocurek and Lancaster (1999), although perhaps the phrase "sediment through-passing" is more appropriate. In any case, the general models presented by Mason (2001) and later by 
(a)

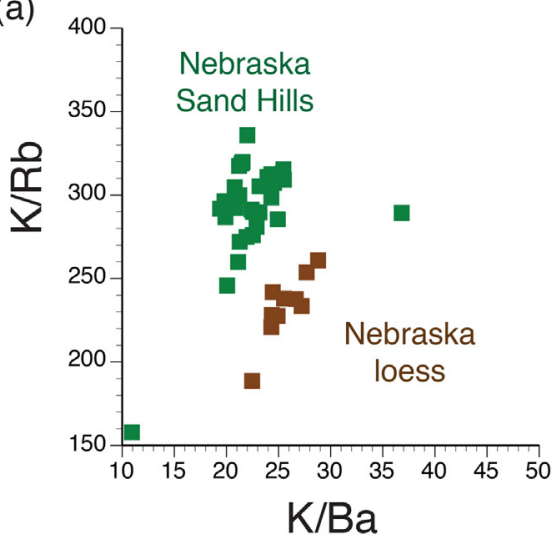

(c)

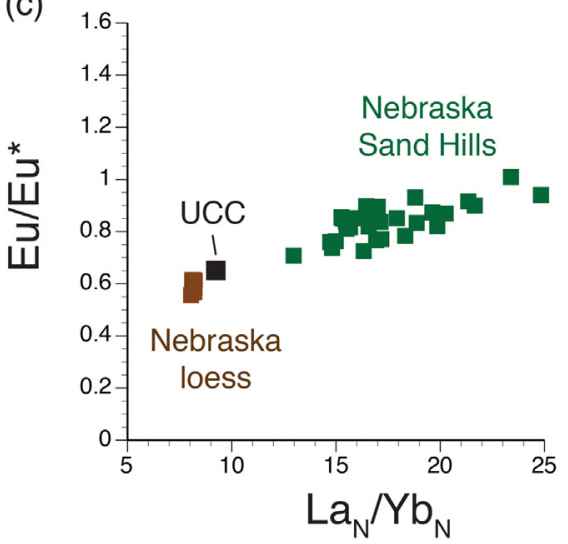

(b)

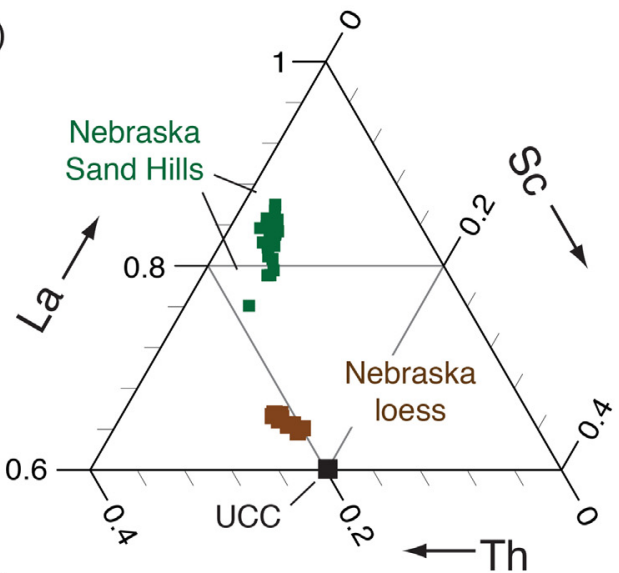

(d)

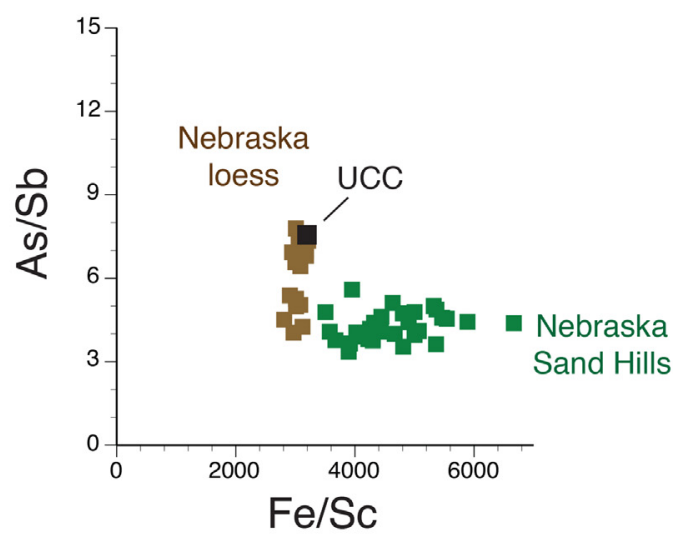

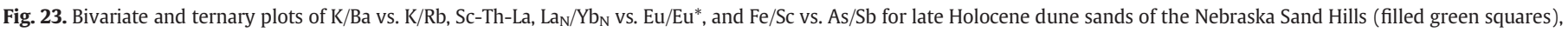

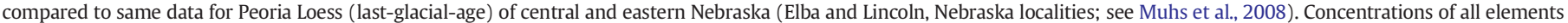
determined by instrumental neutron activation analysis from this study. UCC, upper continental crust; values from Taylor and McLennan (1985).

Muhs et al. (2008) still have validity with the data presented here, because they assume that the dunes and loess had separate sources.

\section{Summary and conclusions}

The Nebraska Sand Hills region is the largest dune field in North America. It hosts a diverse suite of aeolian landforms, including barchanoid ridge, barchan, linear, and parabolic dunes, as well as aeolian sand sheets. Although many of the largest dunes were built during the late Pleistocene, many studies of the past three decades show that Holocene dune activity was widespread in the Nebraska Sand Hills. Furthermore, a minimal degree of soil development in the youngest aeolian sand indicates that virtually all of the dune field has been active during the Holocene, though not necessarily at all localities simultaneously. Modern, sand-moving winds are dominantly from the west, northwest, and north during the fall, winter, and spring, with weaker southerly or southeasterly winds during summer months. Dune morphology indicates that dune-forming winds were dominantly from the northwest during both the late Pleistocene and Holocene.

Identification of the source sediments for the Nebraska Sand Hills has been a challenging problem for the better part of a century. Many investigators have proposed source sediments but with few exceptions, mineralogical or geochemical data to support a specific source or sources have been lacking. Proposed sources include the Arikaree Group and Ogallala Group of Tertiary age, sediments reworked from these units, Pliocene sands that underlie the Nebraska Sand Hills, and fluvial sources such as the Platte River system. We collected representative samples from each of these potential sources, generated separates that approximate the size distribution of the dune sands, and performed mineralogical and geochemical analyses. The mineralogy of the dune sands and all source sediments is dominated by quartz, plagioclase, and K-feldspar, indicating at a broad level of composition, any or all of the hypothesized source sediments could be important.

Trace element geochemistry was performed by high-precision INAA on Holocene dune sediments of the Nebraska Sand Hills and sands from the Arikaree Group, Ogallala Group, Pliocene sediments, and North and South Platte River sediments. K/Rb, K/Ba, Sc-Th-La, Eu/Eu*, La $/ \mathrm{Yb}_{\mathrm{N}}, \mathrm{As} /$ $\mathrm{Sb}$, and $\mathrm{Fe} / \mathrm{Sc}$ all indicate that sediments of the Ogallala Group are the most important sources for the Nebraska Sand Hills. While geochemical evidence indicates that sediment of the Arikaree Group could have been a minor contributor, the highly variable composition of this unit does not always show good compositional agreement with that of the Nebraska Sand Hills. Pliocene sediments are found beneath the Nebraska Sand Hills, and sands of the Platte River system are found to the west, southwest, south, and southeast of the dune field. However, neither of these sediments appear to have been significant sources for the Nebraska Sand Hills. The Ogallala Group is often perceived to be a well-indurated unit, anchored in its upper parts by a cemented calcrete caprock. However, examination of the western Nebraska landscape, both in the field and with topographic maps, shows that a significant amount of the region mapped as the Ogallala Group is quite dissected. Dissected landscapes of western Nebraska not only lack a calcretecemented caprock, but in addition host valley sides mantled by unconsolidated sediment derived from the Ogallala Group. Regionally extensive erosion of the Ogallala Group, perhaps envisioned to be widespread, or even uniform stripping of this unit, during preQuaternary or early Quaternary time has long been hypothesized to have provided the initial material for formation of the Nebraska Sand Hills. While this may have occurred, the present results also show that 
(a)

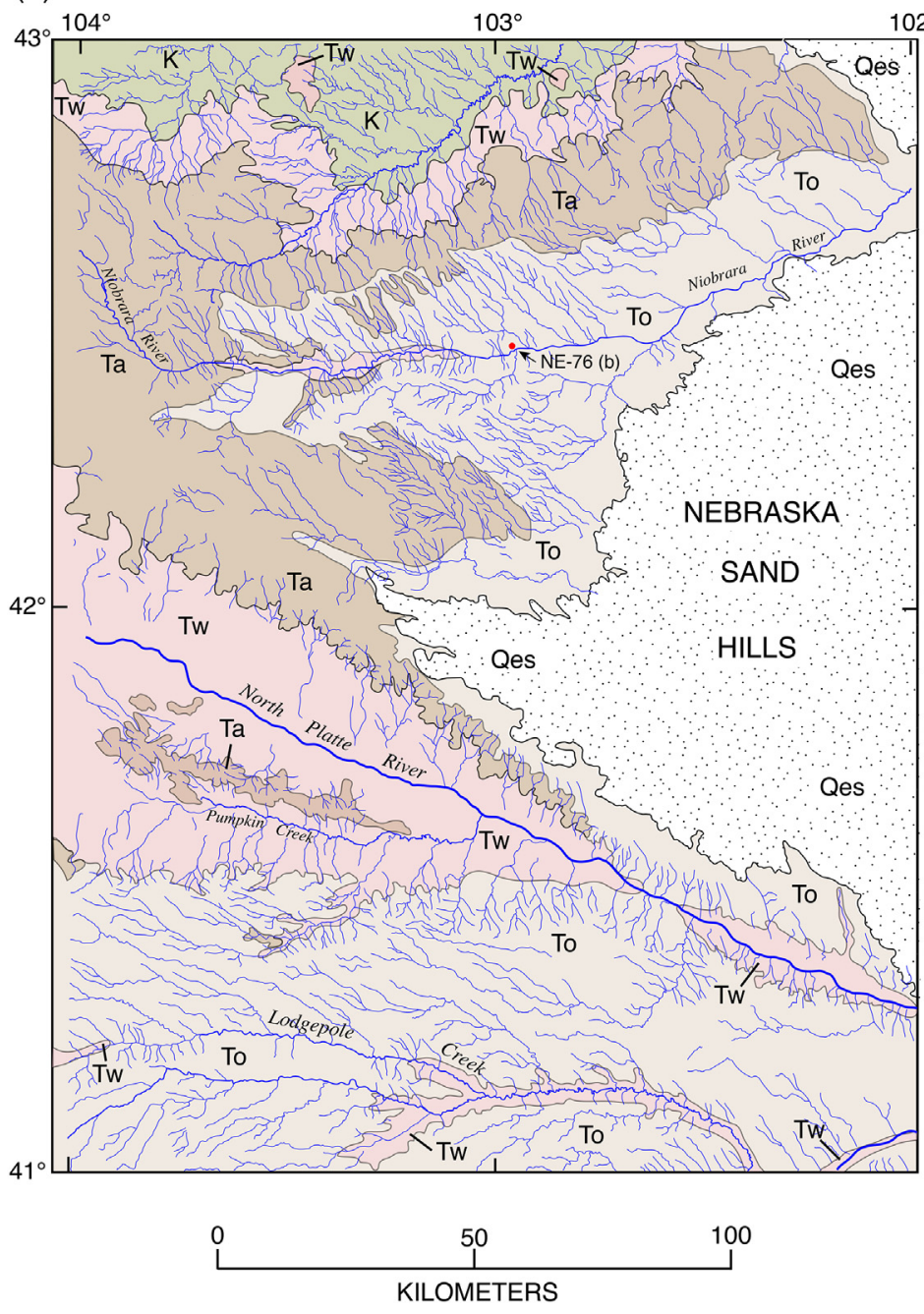

(b) NE-75, 76 area

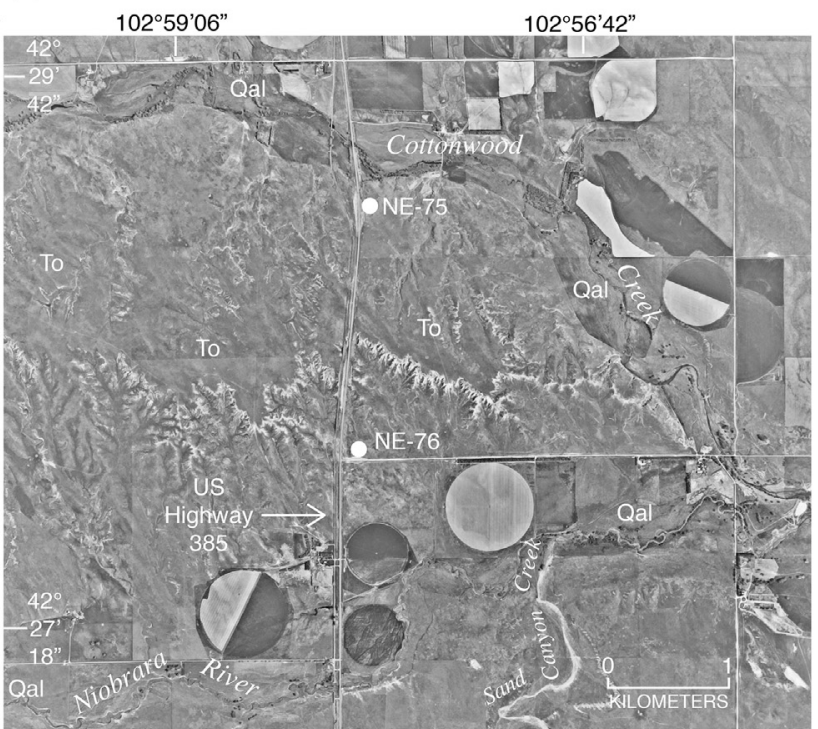

(c) View to north from NE-76 shown in (b):

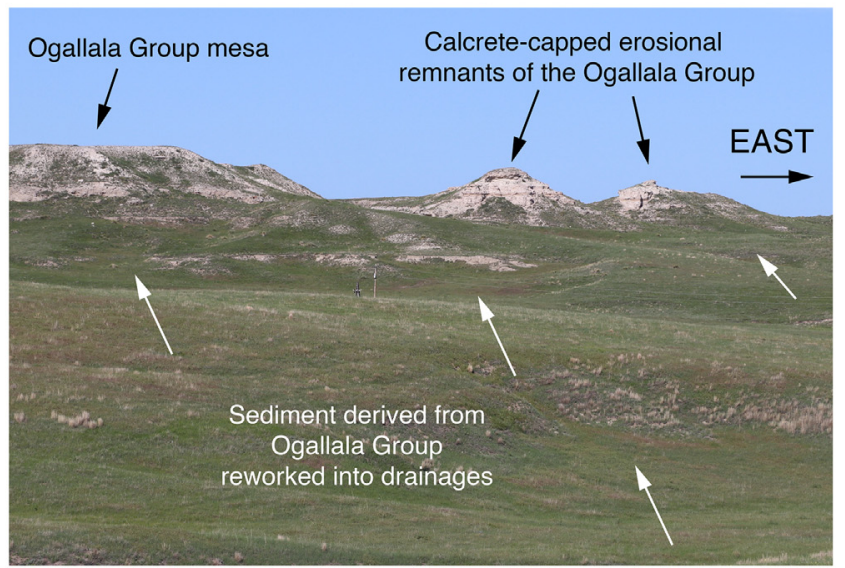

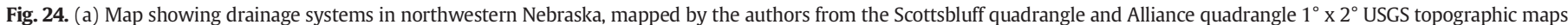

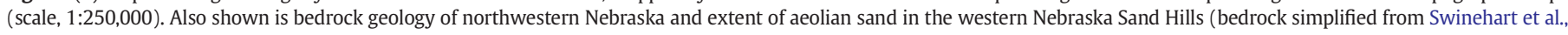

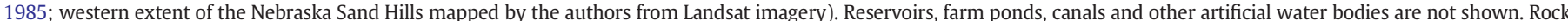

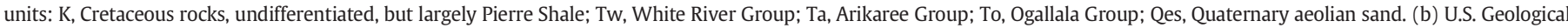

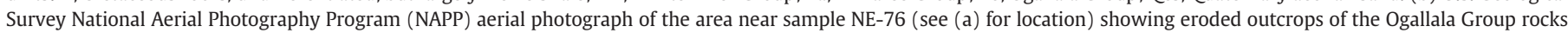

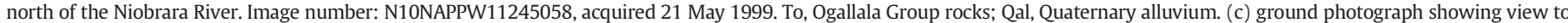

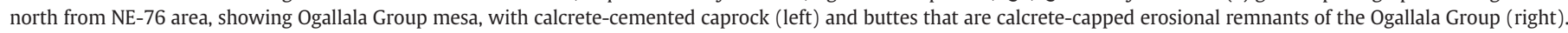
White arrows point to sediment derived from the Ogallala Group eroded into drainages. Photograph by D.R. Muhs.

an Ogallala Group landscape, if minimally vegetated under drought conditions, could have supplied aeolian sand to the Nebraska Sand Hills once dissection had proceeded to the point where loose sediment became available.

Supplementary data to this article can be found online at https://doi. org/10.1016/j.geomorph.2019.02.023.

\section{Acknowledgments}

This study was supported by the Land Change Science Research and Development Program of the U.S. Geological Survey (USGS). John Aleinikoff and Chuck Bush (both USGS, retired) assisted with field work. Dave Loope (University of Nebraska) confirmed our tentative identifications of bison hoofprints, which we appreciate. Scott Cowherd conducted the X-ray diffraction analyses, for which we are grateful. Sincere thanks go to Margaret Berry, Xiaoping Yang, Nick Lancaster, Scott A. Lecce, and Keith Lucey, who commented on earlier versions of the manuscript and improved it. Any use of trade, firm, or product names is for descriptive purposes only and does not imply endorsement by the U.S. government.

\section{References}

Ahlbrandt, T.S., Fryberger, S.G., 1980. Eolian deposits in the Nebraska Sand Hills. U.S. Geol Surv. Prof. Pap. 1120-A, 1-24.

Ahlbrandt, T.S., Swinehart, J.B., Maroney, D.G., 1983. The dynamic Holocene dune fields of the Great Plains and Rocky Mountain basins, U.S.A. In: Brookfield, M.E., Ahlbrandt, T.S. (Eds.), Eolian Sediments and Processes. Elsevier, New York, pp. 379-406.

Aleinikoff, J.N., Muhs, D.R., Bettis III, E.A., Johnson, W.C., Fanning, C.M., Benton, R., 2008 Isotopic evidence for the diversity of late Quaternary loess in Nebraska: glaciogenic and non-glaciogenic sources. Geol. Soc. Am. Bull. 120, 1362-1377.

Berry, M.E., Slate, J.L., Paces, J.B., Hanson, P.R., Brandt, T.R., 2015. Geologic map of the Masters 7.5' quadrangle, Weld and Morgan Counties, Colorado. U.S. Geological Survey Scientific Investigations Map 3344, scale 1:24,000.

Bhatia, M.R., Crook, K.A.W., 1986. Trace element characteristics of graywackes and tectonic setting discrimination of sedimentary basins. Contrib. Mineral. Petrol. 92, 181-193.

Budahn, J.R., Schmitt, R.A., 1985. Petrogenetic modeling of Hawaiian tholeiitic basalts: a geochemical approach. Geochim. Cosmochim. Acta 49, 67-87.

Budahn, J.R., Wandless, G.A., 2002. Instrumental neutron activation by long count. U.S Geol. Surv. X1-X13 (Open-File Report OF 02-0223).

Burchett, R.R., 1969. Geologic bedrock map of Nebraska. Nebraska Geological Survey GMC-1, scale 1:1,000,000.

Clarke, M.L., Rendell, H.M., 2003. Late Holocene dune accretion and episodes of persistent drought in the Great Plains of Northeastern Colorado. J. Arid Environ. 22, 1051-1058. 
Condra, G.E., Reed, E.C., Gordon, E.D., 1947. Correlation of the Pleistocene deposits of Nebraska. Neb. Geol. Surv. Bull. 15 (73 p)

Cooke, R., Warren, A., Goudie, A., 1993. Desert Geomorphology. UCL Press Limited, London (526 pp).

Dane, C.H., Bachman, G.O., 1965. Geologic Map of New Mexico U.S. Geological Survey map. (scale 1:500,000).

Diffendal, R.F., Jr., 1987. Ash Hollow State Historical Park: Type area for the Ash Hollow Formation (Miocene), western Nebraska. Geological Society of America Centennial Field Guide 3-North-Central Section, 29-34.

DiPietro, J.A., 2013. Landscape Evolution in the United States: An Introduction to the Geography, Geology, and Natural History. Elsevier, Waltham, MA (480 pp).

Esson, J., Stevens, R.H., Vincent, E.A., 1965. Aspects of the geochemistry of arsenic and antimony, exemplified by the Skaergaard intrusion. Mineral. Mag. 35, 88-107.

Forman, S.L., Marín, L., Pierson, J., Gómez, J., Miller, G.H., Webb, R.S., 2005. Aeolian sand depositional records from western Nebraska: landscape response to droughts in the past 1500 years. Holocene 15, 973-981.

Frost, C.D., Frost, B.R., Chamberlain, K.R., Edwards, B.R., 1999. Petrogenesis of the 1.43 Ga Sherman batholith, SE Wyoming, USA: a reduced, Rapakivi-type anorogenic granite. J. Petrol. 40, 1771-1802.

Frost, C.D., Frost, B.R., Lindsley, D.H., Chamberlain, K.R., Swapp, S.M., Scoates, J.S., 2010. Geochemical and isotopic evolution of the anorthositic plutons of the Laramie anorthosite complex: explanations for variations in silica activity and oxygen fugacity of massif anorthosites. Can. Mineral. 48, 925-946.

Fryberger, S.G., Dean, G., 1979. Dune forms and wind regime. In: McKee, E.D. (Ed.), A Study of Global Sand Seas. U.S. Geol. Surv. Prof. Pap. 1052, 137-169.

Fryberger, S.G., Schenk, C.J., 1988. Pin-stripe lamination: a distinctive feature of modern and ancient aeolian sediments. Sediment. Geol. 55, 1-15.

Garzanti, E., Andò, S., Vezzoli, G., Lustrino, M., Boni, M., Vermeesch, P., 2012. Petrology of the Namib sand sea: long-distance transport and compositional variability in the wind-displaced Orange Delta. Earth Sci. Rev. 112, 173-189.

Goble, R.J., Mason, J.A., Loope, D.B., Swinehart, J.B., 2004. Optical and radiocarbon ages of stacked paleosols and dune sands in the Nebraska Sand Hills, USA. Quat. Sci. Rev. 23, $1173-1182$

Goudie, A.S., 2002. Great Warm Deserts of the World: Landscapes and Evolution. Oxford University Press, Oxford (480 pp).

Govindaraju, K., 1989. 1989 compilation of working values and sample description for 272 geostandards. Geostand. Newslett. 13, 1-113.

Hack, J.T., 1941. Dunes of the western Navajo country. Geogr. Rev. 31, 240-263.

Halfen, A.F., Lancaster, N., Wolfe, S., 2016. Interpretations and common challenges of aeolian records from North American dune fields. Quat. Int. 410, 75-95.

Hartman, B.M., Scranton, D.F., 1992. Geologic Map of Texas. University of Texas at Austin, Bureau of Economic Geology map, scale of individual sheets, 1:250,000.

Hesse, P.P., 2011. Sticky dunes in a wet desert: Formation, stabilisation and modification of the Australian desert dunefields. Geomorphology 134, 309-325.

Joeckel, R.M., Wooden Jr., S.R., Korus, J.T., Garbisch, J.O., 2014. Architecture, heterogeneity, and origin of late Miocene fluvial deposits hosting the most important aquifer in the Great Plains, USA. Sediment. Geol. 311, 75-95.

Kasper-Zubillaga, J.J., Zolezzi-Ruíz, H., Carranza-Edwards, A., Girón-García, P., Ortiz Zamora, G., Palma, M., 2007. Sedimentological, modal analysis and geochemical studies of desert and coastal dune sands, Altar Desert, NW Mexico. Earth Surf. Process. Landf. 32, 489-508.

Kocurek, G., Lancaster, N., 1999. Aeolian system sediment state: theory and Mojave Desert Kelso dune field example. Sedimentology 46, 505-515.

Kuzila, M., 1990. Soils. In: Bleed, A., Flowerday, C. (Eds.), An Atlas of the Sand Hills. Resource Atlas No. 5a, University of Nebraska-Lincoln, pp. 58-66.

Kuzila, M.S., Mack, A.M., Culver, J.R., Schaefer, S.J., 1990. General Soil Map of Nebraska. Conservation and Survey Division, Institute of Agriculture and Natural Resources, University of Nebraska, Lincoln and U.S. Department of Agriculture Soil Conservation Service.

Lancaster, N., 1988. Development of linear dunes in the southwestern Kalahari, southern Africa. J. Arid Environ. 14, 233-244.

Lancaster, N., 1989. The Namib Sand Sea. A.A. Balkema, Rotterdam (180 pp),

Lancaster, N., 1995. Geomorphology of Desert Dunes. Routledge, London (290 pp).

Lancaster, N., 2007. Dune fields: low latitudes. In: Elias, S. (Ed.), The Encyclopedia of Quaternary Sciences: Elsevier, Amsterdam, pp. 626-642.

Lancaster, N., Helm, P., 2000. A test of a climatic index of dune mobility using measurements from the southwestern United States. Earth Surf. Process. Landf. 25, 197-207.

Lewis, D.T. 1976. Properties of soils in the solid set irrigation area of the Sandhills Agricultural Laboratory. The Agriculture Experiment Station, Institute of Agriculture and Natural Resources, University of Nebraska-Lincoln, Research Bulletin Vol. 278, pp. 1-14

Liu, Q., Yang, X., 2018. Geochemical composition and provenance of aeolian sands in the Ordos Deserts, northern China. Geomorphology 318, 354-374.

Livingstone, I., Warren, A., 1996. Aeolian Geomorphology: An Introduction. Longman, London (211 pp).

Loope, D.B., 1986. Recognizing and utilizing vertebrate tracks in cross section: Cenozoic hoofprints from Nebraska. Palaios 1, 141-151

Loope, D.B., Swinehart, J.B., Mason, J.P., 1995. Dune-dammed paleovalleys of the Nebrask Sand Hills: intrinsic versus climatic controls on the accumulation of lake and marsh sediments. Geol. Soc. Am. Bull. 107, 396-406.

Lorenz, R.D., Zimbelman, J.R., 2014. Dune Worlds: How Windblown Sand Shapes Planetary Landscapes. Springer (308 pp)

Love, J.D., Christiansen, A.C., 1985. Geologic Map of Wyoming U.S. Geological Survey map. (scale 1:500,000)

Lugn, A.L., 1939. Nebraska in relation to the problems of Pleistocene stratigraphy. Am. J. Sci. $237,851-884$
Lugn, A.L., 1962. The origin and sources of loess in the central Great Plains and adjoining areas of the central lowland. Nebraska University Studies, New Series 26, part XI, (105 pp).

Lugn, A.L., 1968. The origin of loesses and their relation to the Great Plains in North America. In: Schultz, C.B., Frye, J.C. (Eds.), Loess and Related Eolian Deposits of the World. University of Nebraska Press, Lincoln, pp. 139-182.

MacFadden, B.J., Hunt Jr., R.M., 1998. Magnetic polarity stratigraphy and correlation of the Arikaree Group, Arikareean (late Oligocene-early Miocene) of northwestern Nebraska. Geol. Soc. Am. Spec. Pap. 325, 143-165.

Madole, R.F., 1995. Spatial and temporal patterns of late Quaternary eolian deposition, eastern Colorado, U.S.A. Quat. Sci. Rev. 14, 155-177.

Madole, R.F., VanSistine, D.P., Michael, J.A., 2005. Distribution of Late Quaternary winddeposited sand in eastern Colorado: U.S. Geological Survey Scientific Investigations Map 2875, scale 1:700,000, (49 p)

Martin, J.E. Sawyer, J.F., Fahrenbach, M.D., Tomhave, D.W., Schulz, L.D., 2004 Geologic map of South Dakota. South Dakota Department of Environment and Natural Resources, Geological Survey General Map 10, scale 1:500,000.

Mason, J.A., 2001. Transport direction of Peoria Loess in Nebraska and implications for loess sources on the central Great Plains. Quat. Res. 56, 79-86.

Mason, J.A., Swinehart, J.B., Goble, R.J., Loope, D.B., 2004. Late-Holocene dune activity linked to hydrological drought, Nebraska Sand Hills, USA. Holocene 14, 209-217.

Mason, J.A., Swinehart, J.B., Hanson, P.R., Loope, D.B., Goble, R.J., Miao, X., Schmeisser, R.L., 2011. Late Pleistocene dune activity in the central Great Plains, USA. Quat. Sci. Rev. 30, 3858-3870.

May, D.W., Swinehart, J.B., Loope, D., Souders, V., 1995. Late Quaternary fluvial and eolian sediments: Loup River Basin and the Nebraska Sand Hills. In: Diffendal, R.F., Jr., Flowerday, C.A. (Eds.), Geologic Field Trips in Nebraska and Adjacent Parts of Kansas and South Dakota. Conservation and Survey Division, Institute of Agriculture and Natural Resources, University of Nebraska-Lincoln, Guidebook No. 10, p. 13-31.

McLennan, S.M., 1989. Rare earth elements in sedimentary rocks: influence of provenance and sedimentary processes. Rev. Mineral. 21, 169-200.

Miao, X.D., Mason, J.A., Swinehart, J.B., Loope, D.B., Hanson, P.R., Goble, R.J., Liu, X.D., 2007. A 10,000 year record of dune activity, dust storms, and severe drought in the central Great Plains. Geology 35, 119-122.

Morrison, R.B., 1969. Photointerpretive mapping from space photographs of Quaternary geomorphic features and soil associations in northern Chihuahua and adjoining New Mexico and Texas. In: Cordoba, D.A., Wengerd, S.A., Shomaker, J. (Eds.), Guidebook of the Border Region. New Mexico Geological Society, Twentieth Field Conference, pp. 116-129.

Muhs, D.R., 2017. Evaluation of simple geochemical indicators of aeolian sand provenance: Late Quaternary dune fields of North America revisited. Quat. Sci. Rev. 171, 260-296.

Muhs, D.R., 2018. The geochemistry of loess: Asian and north American deposits compared. J. Asian Earth Sci. 155, 81-115.

Muhs, D.R., Budahn, J.R., 2006. Geochemical evidence for the origin of late Quaternary loess in central Alaska. Can. J. Earth Sci. 43, 323-337.

Muhs, D.R., Holliday, V.T., 1995. Evidence for active dune sand on the Great Plains in the 19th century from accounts of early explorers. Quat. Res. 43, 198-208.

Muhs, D.R., Maat, P.B., 1993. The potential response of eolian sands to greenhouse warming and precipitation reduction on the Great Plains of the U.S.A. J. Arid Environ. 25, 351-361

Muhs, D.R., Stafford, T.W., Cowherd, S.D., Mahan, S.A., Kihl, R., Maat, P.B., Bush, C.A., Nehring. J., 1996. Origin of the late Quaternary dune fields of northeastern Colorado. Geomorphology 17, 129-149.

Muhs, D.R., Stafford Jr., T.W., Swinehart, J.B., Cowherd, S.D., Mahan, S.A., Bush, C.A., 1997. Late Holocene eolian activity in the mineralogically mature Nebraska Sand Hills. Quat. Res. 48, 162-176.

Muhs, D.R., Bettis III, E.A., Aleinikoff, J., McGeehin, J.P., Beann, J., Skipp, G., Marshall, B.D., Roberts, H.M., Johnson, W.C., Benton, R., 2008. Origin and paleoclimatic significance of late Quaternary loess in Nebraska: evidence from stratigraphy, chronology, sedimentology, and geochemistry. Geol. Soc. Am. Bull. 120, 1378-1407.

Muhs, D.R., Roskin, J., Tsoar, H., Skipp, G., Budahn, J.R., Sneh, A., Porat, N., Stanley, J.-D. Katra, I., Blumberg, D.G., 2013. Origin of the Sinai-Negev erg, Egypt and Israel: mineralogical and geochemical evidence for the importance of the Nile and sea level history. Quat. Sci. Rev. 69, 28-48.

Myers, M., 1993. A Pliocene Eolian Sand Sheet Beneath the Nebraska Sand Hills. Unpublished M.S. thesis, University of Nebraska, Lincoln.

Olivarez, A.M., Owen, R.M., Rea, D.K., 1991. Geochemistry of eolian dust in Pacific pelagic sediments: implications for paleoclimatic interpretations. Geochim. Cosmochim. Acta $55,2147-2158$.

Onishi, H., Sandell, E.B., 1955. Geochemistry of arsenic. Geochim. Cosmochim. Acta 7, $1-33$.

Pettijohn, F.J., Potter, P.E., Siever, R., 1972. Sand and Sandstone. Springer-Verlag, New York (618 pp)

Pye, K., Tsoar, H., 1990. Aeolian Sand and Sand Dunes. Unwin Hyman, London (396 pp).

Reed, E.C. 1968. Loess deposition in Nebraska. In: Schultz, C.B. Frye, J.C. (Eds.), Loess and Related Eolian Deposits of the World. University of Nebraska Press, Lincoln, pp. 139-182.

Roberts, H.M., Muhs, D.R., Wintle, A.G., Duller, G.A.T., Bettis III, E.A., 2003. Unprecedented last glacial mass accumulation rates determined by luminescence dating of loess from western Nebraska. Quat. Res. 59, 411-419.

Ross, J.A., Wong, M.K., Chyn, H.M., Wong, R.K.W., Kirshen, D.S., Wong, W.K., Collins, D.R., Ross, C.G., Brady, L.R., 1991. Geologic Map of Kansas. Kansas Geological Survey, Map Series 23, scale, 1:500,000. 
Schmeisser McKean, R.L., Goble, R.J., Mason, J.B., Swinehart, J.B., Loope, D.B., 2015. Temporal and spatial variability in dune reactivation across the Nebraska Sand Hills, USA. The Holocene 25, 523-535.

Schmeisser, R.L., Loope, D.B., Mason, J.A., 2010. Modern and late Holocene wind regimes over the Great Plains (central U.S.A.). Quat. Sci. Rev. 29, 554-566.

Scott, G.R., 1968. Geologic and structure contour map of the La Junta quadrangle, Colorado and Kansas. U.S. Geological Survey Miscellaneous Investigations Series Map I-560, scale $1: 250,000$.

Scott, G.R., 1978. Map showing geology, structure, and oil and gas fields in the Sterling $1^{\circ}$ X $2^{\circ}$ quadrangle, Colorado, Nebraska, and Kansas. U.S. Geological Survey Miscellaneous Investigations Series Map 1092, scale 1:250,000.

Sharps, J.A., 1976. Geologic map of the Lamar quadrangle, Colorado and Kansas. U.S. Geological Survey Miscellaneous Investigations Series Map I-944, scale 1:250,000.

Sharps, J.A., 1980. Geologic Map of the Limon $1^{\circ}$ x $2^{\circ}$ Quadrangle, Colorado and Kansas. U.S. Geological Survey Miscellaneous Investigations Series Map I-1250, scale 1: 250,000 .

Smith, H.T.U., 1965. Dune morphology and chronology in central and western Nebraska. J. Geol. 73, 557-578.

Soller, D.R., Reheis, M.C., 2004. Surficial materials in the conterminous United States. U.S. Geological Survey Open-File Report OFR-03-275.

Sridhar, V., Loope, D.B., Swinehart, J.B., Mason, J.A., Oglesby, R.J., Rowe, C.M., 2006. Large wind shift on the Great Plains during the medieval warm period. Science 313, 345-347.

Stanley, K.O., 1976. Sandstone petrofacies in the Cenozoic High Plains sequence, eastern Wyoming and Nebraska. Geol. Soc. Am. Bull. 87, 297-309.

Stokes, S., Swinehart, J.B., 1997. Middle- and late-Holocene dune reactivation in the Nebraska Sand Hills, USA. The Holocene 7, 263-272.

Sun, J., Muhs, D.R., 2007. Dune fields: Mid-latitudes. In: Elias, S. (Ed.), The Encyclopedia of Quaternary Sciences: Elsevier, Amsterdam, pp. 607-626.

Sun, J., Li, S.-H., Muhs, D.R., Li, B., 2007. Loess sedimentation in Tibet: provenance, processes, and link with Quaternary glaciations. Quat. Sci. Rev. 26, 2265-2280.

Swinehart, J.B., 1990. Wind-blown Deposits. In: Bleed, A., Flowerday, C. (Eds.), An Atlas of the Sand Hills. Resource Atlas no. 5a, University of Nebraska-Lincoln, pp. 43-56.

Swinehart, J.B., Diffendal, R.F., Jr., 1987. Duer Ranch, Morrill County, Nebraska: Contrast between Cenozoic fluvial and eolian deposition. Geological Society of America Centennial Field Guide 3-North-Central Section, 23-28.

Swinehart, J.B., Diffendal, R.F., Jr., 1990. Geology of the pre-dune strata. In: Bleed, A., Flowerday, C. (Eds.), An Atlas of the Sand Hills. Resource Atlas No. 5a, University of Nebraska-Lincoln, pp. 29-42.

Swinehart, J.B., Loope, D.B., 1987. Late Cenozoic geology along the summit to museum hiking trail, Scotts Bluff National Monument, western Nebraska. Geological Society of America Centennial Field Guide 3-North-Central Section, 13-18.

Swinehart, J.B., Souders, V.L., DeGraw, H.M., Diffendal Jr., R.F., 1985. Cenozoic paleogeography of western Nebraska. In: Flores, R.M., Kaplan, S.S. (Eds.), Cenozoic Paleogeography of West-Central United States. Rocky Mountain Section of the Society of Economic Paleontologists and Mineralogists, Denver, pp. 209-229.

Swinehart, J. B., Dreeszen, V. H., Richmond, G. M., Tipton, M. J., Bretz, R., Steece, F. V. Hallberg, G. R., Goebel, J. E., 1994a. Quaternary Geologic Map of the Platte River $4^{\circ}$ x $6^{\circ}$ Quadrangle, United States. U.S. Geological Survey Miscellaneous Investigations Series Map I-1420 (NK-14). Scale 1:1,000,000.
Swinehart, J.B., Loope, D., Ponte, M., Mason, J., Helland, P., Kim, N., 1994b. Paleoenvironments of the Nebraska Sand Hills. Society for Sedimentary Geology, Midcontinent Section, Field Trip Guidebook. Lincoln, University of Nebraska (40 pp).

Taylor, S.R., McLennan, S.M., 1985. The Continental Crust: Its Composition and Evolution. Blackwell Scientific Publications, Oxford (312 pp).

Thornbury, W.D., 1965. Regional Geomorphology of the United States. John Wiley \& Sons, Inc., New York (609 pp).

Tsoar, H., 2005. Sand dunes mobility and stability in relation to climate. Physica A 357 50-56.

Tsoar, H., Levin, N., Porat, N., Maia, L.P., Herrmann, H.J., Tatumi, S.H., Claudino-Sales, V., 2009. The effect of climate change on the mobility and stability of coastal sand dunes in Ceará State (NE Brazil). Quat. Res. 71, 217-226.

Tweto, O., 1979. Geologic map of Colorado. U.S. Geological Survey, scale 1:500,000.

Warren, A., 1976. Morphology and sediments of the Nebraska Sand Hills in relation to Pleistocene winds and the development of eolian bedforms. J. Geol. 84, 685-700.

Warren, A., 2013. Dunes. John Wiley \& Sons, Ltd., Chichester, (219 pp).

Westin, F.C., Bannister, D.L., Huron, S.D., 1971. Soil Associations of South Dakota. AES Information Series No. 3, Agricultural Experiment Station, South Dakota State University, Brookings, and U.S. Department of Agriculture Soil Conservation Service, Huron.

Williams, G.P., 1978. The case of the shrinking channels-the North Platte and Platte Rivers in Nebraska. U.S. Geological Survey Circular 781.

Wilson, I.G., 1973. Ergs. Sedimentary Geology 10, 77-106.

Winspear, N.R., Pye, K., 1996. Textural, geochemical and mineralogical evidence for the sources of aeolian sand in central and southwestern Nebraska, U.S.A. Sediment Geol. 101, 85-98.

Wolfe, S.A., 1997. Impact of increased aridity on sand dune activity in the Canadian Prairies. J. Arid Environ. 36, 421-432.

Wolfe, S.A., 2007. Dune fields: high latitudes. In: Elias, S. (Ed.), The Encyclopedia of Quaternary Sciences. Elsevier, Amsterdam, pp. 599-607.

Wright Jr., H.E., 1970. Vegetational history of the Central Plains. In: Dort Jr., W., Jones Jr. J.K. (Eds.), Pleistocene and Recent Environments of the Central Great Plains. Department of Geology Special Publication, University of Kansas, Lawrence, pp. 157-172.

Wright Jr., H.E., Almendinger, J.C., Grüger, J., 1985. Pollen diagram from the Nebraska Sandhills and the age of the dunes. Quat. Res. 24, 115-120.

Yang, X., Rost, K.T., Lehmkuhl, F., Zhenda, Z., Dodson, J., 2004. The evolution of dry lands in northern China and in the Republic of Mongolia since the Last Glacial Maximum. Quat. Int. 118-119, 69-85.

Yang, X., Zhu, B., White, P.D., 2007. Provenance of aeolian sediment in the Taklamakan Desert of western China, inferred from REE and major-elemental data. Quat. Int. 175, 71-85.

Yizhaq, H.Y., Ashkenazy, Y., Tsoar, H., 2009. Sand dune dynamics and climate change: a modeling approach. J. Geophys. Res. 114, F01023. https://doi.org/10.1029/ 2008JF001138.

Zárate, M.A., Tripaldi, A., 2012. The aeolian system of central Argentina. Aeolian Res. 3, 401-417. 